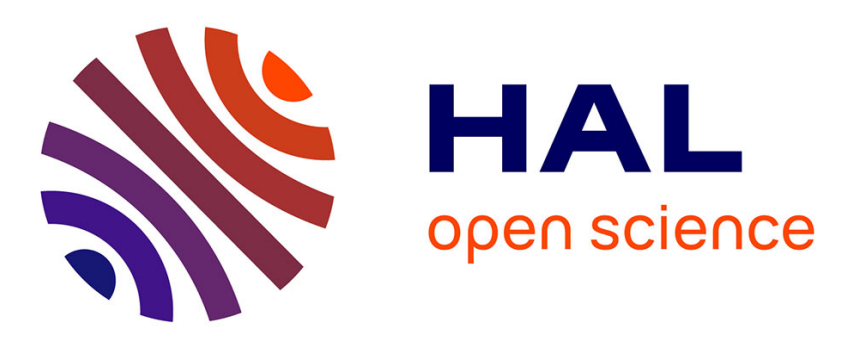

\title{
Geochemical evidence for mixing between fluids exsolved at different depths in the magmatic system of Mt Etna (Italy)
}

Antonio Paonita, A. Caracausi, Giada Iacono-Marziano, M. Martelli, Andrea Rizzo

\section{To cite this version:}

Antonio Paonita, A. Caracausi, Giada Iacono-Marziano, M. Martelli, Andrea Rizzo. Geochemical evidence for mixing between fluids exsolved at different depths in the magmatic system of Mt Etna (Italy). Geochimica et Cosmochimica Acta, 2012, 84, pp.380-394. 10.1016/j.gca.2012.01.028 . insu00671974

\section{HAL Id: insu-00671974 https://hal-insu.archives-ouvertes.fr/insu-00671974}

Submitted on 22 Mar 2012

HAL is a multi-disciplinary open access archive for the deposit and dissemination of scientific research documents, whether they are published or not. The documents may come from teaching and research institutions in France or abroad, or from public or private research centers.
L'archive ouverte pluridisciplinaire HAL, est destinée au dépôt et à la diffusion de documents scientifiques de niveau recherche, publiés ou non, émanant des établissements d'enseignement et de recherche français ou étrangers, des laboratoires publics ou privés. 


\title{
GEOCHEMICAL EVIDENCE FOR MIXING BETWEEN FLUIDS EXSOLVED AT DIFFERENT DEPTHS IN THE MAGMATIC SYSTEM OF MT ETNA (ITALY)
}

\author{
A. Paonita ${ }^{\circ *}$, A. Caracausi*, G. Iacono-Marziano ${ }^{+}$, M. Martelli*, A. Rizzo* \\ *Istituto Nazionale di Geofisica e Vulcanologia - Sezione di Palermo, \\ Via Ugo La Malfa 153, 90146 Palermo (Italy) \\ ${ }^{+}$CNRS, INSU, Université d'Orléans, Institut des Sciences de la Terre d'Orléans (ISTO), \\ UMR 6113 CNRS, Orléans Cedex 2, France
}

${ }^{\circ}$ Corresponding Author: a.paonita@pa.ingv.it

REVISED VERSION, 07/11/2011 


\begin{abstract}
A 4-year geochemical survey of some fumaroles at the Voragine summit crater of Mt Etna was performed in combination with synchronous monitoring of peripheral gas emissions at the base of the volcano. This was the first geochemical study at Mt Etna to have included the abundances of Ar, $\mathrm{He}$, and $\mathrm{C}$ isotopes. Once the effects of postmagmatic shallow processes were identified and quantitatively removed, the $\mathrm{He}-\mathrm{Ar}-\mathrm{CO}_{2}$ systematics of the Voragine crater fumaroles and peripheral gas emissions described the same degassing path. Combining the carbon-isotope composition with information about noble gases provided evidence that the crater fumaroles are fed from a twoendmember mixture composed of a deep member coming from pressures between 200 and $400 \mathrm{MPa}$ (depending on time), and a shallower one exsolved at $130 \mathrm{MPa}$. Similar mixing processes probably also occur in gases from peripheral vents. The simultaneous assessment of $\delta^{13} \mathrm{C}_{\mathrm{CO} 2}$ and He/Ar values of crater fumaroles over time has identified simple changes in the mixing proportion between the two endmembers and, moreover, periods during which the exsolution pressure of the deep fluid increased. These periods seem to be linked to pre-eruptive phases of the volcano. The identified open-system degassing processes are indicative of efficient bubble-melt decoupling at depth, whereas the mixing process requires a convective transfer of the deeply exsolved fluids toward shallower levels of magma where further vapor is exsolved. In agreement with the most recent geophysical and petrological data from Mt Etna, these observations allow inferences about a deep portion of the plumbing system (5 to $12 \mathrm{~km}$ b.s.l.), comprising sill-like reservoirs connected by small vertical structures, and a main reservoir at $2-3 \mathrm{~km}$ b.s.l. that is probably fluxed by magmatic volatiles.
\end{abstract}




\section{INTRODUCTION}

Modern views of volcano plumbing systems are moving away from the simple model of a single well-shaped magma chamber connected to the surface by a volcanic conduit. Instead, the results from various approaches have revealed intricate systems of dikes, sills, and small chambers with irregular shapes that extend upward through the crust (Preston, 2001; Dawson et al., 2004; Marsh, 2004; Thomson, 2004; Cartwright and Hansen, 2006; Zellmer and Annen, 2008; Paulatto et al., 2010). The geometries of these bodies will clearly control the degree of hydraulic continuity and connectivity, and they somewhat hamper simple magma migration through the entire plumbing system. Horizontally elongated structures can represent traps where further magma ascent is inhibited. In such conditions, bubbly suspensions can develop at the top of the reservoirs by protracted accumulation of gas vesicles ascending through the melt body. As a consequence, magma degassing from complex volcano plumbing systems cannot be modeled by a simple closed system, with instead multiple steps being required to represent decoupling in the bubble-melt system. According to this view, recent geochemical studies have modeled magma degassing by

multiple steps during which the system opens, as at Mt St. Helens (Berlo et al., 2004), Soufriere Hills (Edmonds et al., 2010), and mid-ocean ridges (Paonita and Martelli, 2007). It is reasonable to hypothesize that such conditions will result in the mixing of magma fluids coming from different levels of the plumbing system before they reach the surface (Edmonds et al., 2010).

The present study aimed to determine the coupling processes of multistep degassing and mixing of fluids coming from different levels of the magmatic system at Mt Etna. The peculiar internal structure of this volcano makes it a natural laboratory for this topic, with the seismic tomography of Mt Etna volcano describing the plumbing system in the form of interconnected dikes and sills (Hirn et al., 1997; Chiarabba et al., 2000; De Gori et al., 2005; Aloisi et al., 2009). The discovery of $\mathrm{CO}_{2}-$ rich melt inclusions in recent volcanites (Metrich et al., 2004; Spilliaert et al., 2006; Collins et al., 2009), as well as the observed enrichments of fluid mobile trace elements (Ferlito et al., 2007; Ferlito and Lanzafame, 2010) suggest that deep magmatic fluids can flush shallower magma bodies 
in such a complex geometry. The supply of deep $\mathrm{CO}_{2}$-rich vapors to resident magmas in the conduit system would be also reflected in the chemical composition of the volcanic plume (Aiuppa et al., 2007, 2010; Shinohara et al., 2008). The plume geochemistry would give evidence of a branched geometry of the conduits that is capable of driving partial segregation between the gas and melt (La Spina et al., 2010).

In this framework, the geochemistry of gas emissions located at the base of Mt Etna provides insights into the depths at which the magmatic volatiles exsolve, and has been used to identify two levels of magma storage at depth (Caracausi et al., 2003b; Rizzo et al., 2006). Nevertheless, the location of the sampling sites-being no more than $300 \mathrm{~m}$ a.s.l. and far from the volcanic conduits - means that they cannot provide information on magma degassing and arrival of deep fluids to shallower levels of the magma system. To overcome this limitation, we have performed a medium-term geochemical survey of some fumaroles at the summit craters of Mt Etna. This monitoring has been combined with synchronous monitoring of the well-studied peripheral emissions, with the aim of revealing the genetic relationships between gases collected at different altitudes of the volcano. This was the first geochemical study at Mt Etna to include the abundances and isotope compositions of Ar, He, and C. The gas geochemistry indicates that processes of opensystem degassing are commonly coupled to mixing of vapors coming from deep and shallow portions of the magmatic system.

\section{PREVIOUS STUDIES OF THE INVESTIGATED GAS DISCHARGES}

\subsection{Peripheral vents}

The chemical compositions of some distinctive gas discharges sited around the periphery of Mt Etna volcano have been regularly monitored since 1996 (Caracausi et al., 2003a,b; Rizzo et al., 2006). The gas manifestations are located on the northeast [Fondachello (Fd)] and southwest [Stadio (St), Vallone Salato (VS), and P39] sides of Mt Etna (Fig. 1), as well as on the Hyblean 
foreland far from the volcano (Naftia, not discussed in this article), along the northeast-southwest regional trending fault. Comparing the He-isotope compositions of the discharged gases $[\mathrm{R} / \mathrm{Ra}=6.7 \pm 0.9$ (mean $\pm \mathrm{SD})$, where $\mathrm{R}$ is the sample ${ }^{3} \mathrm{He} /{ }^{4} \mathrm{He}$-isotope ratio and $\mathrm{Ra}$ is the ratio in the atmosphere] and the fluid inclusions trapped in olivine phenocrysts of Etnean lavas $(\mathrm{R} / \mathrm{Ra}=6.8 \pm 0.3)$ suggests that these gases originate from magma (Nuccio et al., 2008).

Variable extents of interaction of $\mathrm{CO}_{2}$-rich fluids with a geothermal aquifer have been proposed to explain the opposite variations in the $\mathrm{He}$ and $\mathrm{CO}_{2}$ fluxes from soils that have been measured in the Paternò area (see Fig. 1; Giammanco et al., 1998), where the presence of hydrothermal bodies had been already suggested (Chiodini et al., 1996; D’Alessandro et al., 1997). The chemical interaction of magmatic fluids with shallow hydrothermal aquifers causes more $\mathrm{CO}_{2}$ than noble gases to be dissolved in water (due to the higher solubility of $\mathrm{CO}_{2}$ ), therefore the residual gas mixture is richer in noble gases than in $\mathrm{CO}_{2}$ (Caracausi et al., 2003b). This process has been quantitatively modeled by considering that each species in the magmatic gases dissolves into an infinitesimal parcel of gas-free hot water up to saturation, with this process being incrementally repeated until the results are consistent with the chemical composition measured in the collected gases (Caracausi et al., 2003b). The degree of dissolution vary markedly among the sites, ranging from very modest dissolution at $\mathrm{St}$ up to the almost total $\mathrm{CO}_{2}$ removal at $\mathrm{Fd}$. This method has not been extended to carbon-isotope fractionations because it critically depends on the temperature and especially the $\mathrm{pH}$ of the hydrothermal aquifers, which are not sufficiently constrained.

After filtering out the dissolution-driven effects, $\mathrm{He} / \mathrm{CO}_{2}$ and $\mathrm{He} / \mathrm{Ne}$ ratios of pristine gases exhibit parallel variations over time, compatible with a process of chemical fractionation due to magma degassing. Modeling this process has made it possible to locate two main magma reservoirs at depth (Caracausi et al., 2003b; Rizzo et al., 2006).

\subsection{Fumaroles of the Voragine crater}


In summer 2007 and 2008, gas emissions that were virtually free of air were sampled for the first time in the crater area, consisting of a group of fumaroles extending along the eastward rim of the Voragine summit crater, which discharged vapors at near-boiling conditions. The contents of He and $\mathrm{C}$ isotopes indicated a magmatic origin (Martelli et al., 2008), while the contents of acidic species revealed an unusual geochemical feature - the vapors preserved appreciable contents of sulfur while $\mathrm{HCl}$ was not detectable (Liotta et al., 2010). This led to Liotta et al. (2010) proposing a selective scrubbing of certain gas components due to the interaction of the magma fluids with hydrothermal solutions. A quantitative investigation of the thermobaric conditions under which this process was acting revealed that large fractionations between $\mathrm{S}$ and $\mathrm{Cl}$ can occur only when gas mixture incrementally interacts with hydrothermal liquid at temperatures and pressures higher than $260^{\circ} \mathrm{C}$ and $5 \mathrm{MPa}$. Moreover, the extent of hydrothermal interactions capable of producing the $\mathrm{CO}_{2} / \mathrm{S}, \mathrm{SO}_{2} / \mathrm{HCl}$, and $\mathrm{SO}_{2} / \mathrm{H}_{2} \mathrm{~S}$ ratios of the crater fumaroles was assessed starting from the ratios between $\mathrm{CO}_{2}, \mathrm{~S}$, and $\mathrm{Cl}$ in the plume; this revealed that about $40 \%$ of gaseous $\mathrm{CO}_{2}$ was scrubbed in the hot water (Liotta et al., 2010). The acidity of the hydrothermal solution did not allow $\mathrm{CO}_{2}$ speciation in water, and thus $\mathrm{CO}_{2, \mathrm{aq}}$ was the only dissolved carbon species (Liotta et al., 2010). Due to the lack of isotope fractionation between $\mathrm{CO}_{2, \text { as }}$ and $\mathrm{CO}_{2, \text { aq }}$ at temperatures higher than $100^{\circ} \mathrm{C}$ (Ohmoto and Rye, 1979), the hydrothermal scrubbing did not affect the $\delta^{13} \mathrm{C}_{\mathrm{CO} 2}$ value of the pristine magmatic vapor. Accordingly, Liotta et al. (2010) performed the first measurements of $\delta^{13} \mathrm{C}_{\mathrm{CO} 2}$ of the Etnean plume, and they found values of $-1.2 \pm 0.5 \%$ (versus PDB), overlapping those of the fumaroles $(-1.8 \pm 0.9 \%$ o). The plume values were also confirmed in measurements by Chiodini et al. (2010).

\section{SAMPLING AND ANALYSES}

We collected gas samples from the peripheral vents at St, Fd, P39, and VS (Fig. 1) during the period 2005-2010 at a frequency of about two samples per month. Since summer 2007, three fumaroles at Voragine crater rim, mutually separated by a few meters, were sampled during the warmer months 
of year, at the same times as the peripheral sites (see Liotta et al., 2010). These emissions consisted of fluids discharged at about $90{ }^{\circ} \mathrm{C}$, namely the boiling point of water at the altitude of the fumarolic field (3250 m a.s.1.; 700 mbar).

Gaseous samples were collected by means of a stainless-steel funnel in the case of bubbling mud volcanoes, or through a probe inserted 50 and $100 \mathrm{~cm}$ into the emission orifice as regards soil and fumarolic gases respectively. Gas was first pumped into a $100 \mathrm{~cm}^{3}$ syringe and then injected into the sample containers (with volume about $20-30 \mathrm{~cm}^{3}$ ) by using three-way valve. Air was purged away from containers by means of several cycles of pumping and injection. Two-ways Pyrex bottles, with vacuum valves at both ends, were used as containers for measurements of major and reactive gases. Two-ways stainless steel tubes, with swagelok valves at both ends, were instead employed to contain samples for noble gas analyses.

In all samples, the concentrations of $\mathrm{CO}_{2}, \mathrm{CH}_{4}, \mathrm{~N}_{2}, \mathrm{O}_{2}, \mathrm{He}, \mathrm{CO}$, and $\mathrm{H}_{2}$ were routinely measured by a Perkin Elmer Clarus 500 gas chromatograph equipped with a 3.5-m Carboxen 1000 column and double detector (hot-wire detector and flame ionization detector), with analytical errors of $<3 \%$. Gas aliquots for noble gas analyses were introduced into ultra-high-vacuum lines for standard purification procedures to remove major and reactive species. The abundances and isotope compositions of $\mathrm{Ar}$ were measured in a multicollector mass spectrometer (Argus). Neon was cryogenically separated from $\mathrm{He}$ at $77 \mathrm{~K}$ after absorption in a charcoal trap cooled at $12 \mathrm{~K}$, connected to the final part of the purification line. The abundances and isotope compositions of He, as well the ${ }^{4} \mathrm{He} /{ }^{20} \mathrm{Ne}$ ratios, were then determined by separately admitting $\mathrm{He}$ and $\mathrm{Ne}$ into a split flight tube mass spectrometer (Helix SFT). Calibration for measurements of elemental and isotopic abundances of He and Ar were performed by using the atmospheric standard. The analytical errors of the Heand Ar-isotope analyses were less than $0.3 \%$ and $0.1 \%$, respectively. Gas samples for carbon isotope analysis were introduced into vacuum lines for standard purification procedures. After removing sulfur species by using lead acetate filters, $\mathrm{CO}_{2}$ was cryogenically purified and admitted to a Finnigan Delta Plus dual inlet mass spectrometer for carbon isotopic determinations. 
Calibration was performed by using a $\mathrm{CO}_{2}$ working standard, prepared by quantitative reaction of a certified Carrara Marble sample $\left(\delta^{13} \mathrm{C}_{\mathrm{MAB}}=+2.45 \%\right.$ vs $\left.\mathrm{PDB}\right)$ with pure $\mathrm{H}_{3} \mathrm{PO}_{4}$. Isotopic compositions of $\mathrm{CO}_{2}$ are given in $\delta^{13} \mathrm{C}_{\mathrm{CO} 2}$ versus $\mathrm{PDB}$, with standard deviation lower than $0.2 \%$.

The complete dataset from 2005 to 2010 is available as an electronic annex to this paper. For the crater fumaroles, we inserted all available data since summer 2007, also including those already reported in our previous articles (Martelli et al., 2008; Liotta et al., 2010), because Ar-isotope and some of the He-isotope values were not reported previously.

\section{GEOCHEMICAL INFERENCES FROM THE AR SURVEY}

\subsection{Peripheral vents}

The peripheral emissions displayed highly variable Ar concentrations, from a few tenths of ppm of St gases up to some thousands at $\mathrm{Fd}$. The measured ${ }^{40} \mathrm{Ar} /{ }^{36} \mathrm{Ar}$ ratios ranged from close to those of the atmosphere (i.e. 295.5) up to 1800. Although lower than typical ratios of fluids from the upper mantle $\left({ }^{40} \mathrm{Ar} /{ }^{36} \mathrm{Ar}>40000\right.$; Burnard et al., 1997; Fischer et al., 2005), the ${ }^{40} \mathrm{Ar} /{ }^{36} \mathrm{Ar}$ ratios fell within the range of subduction-related volcanism (Hilton et al., 2002), thereby indicating an important contribution from magmatic gases to the peripheral vents. A plot of ${ }^{36} \mathrm{Ar} /{ }^{40} \mathrm{Ar}$ ratio versus $\mathrm{Ar}$ content, where binary mixing is represented by straight lines, clearly displays that the Ar-rich endmember can be definitely ascribed to the atmosphere for all of the sites (Fig. 2). The Ar content of each sample could be corrected for its air contamination by computing the relationship Ar* $=$ ${ }^{40} \mathrm{Ar}-\left({ }^{40} \mathrm{Ar} /{ }^{36} \mathrm{Ar}\right)_{\mathrm{air}} \times{ }^{36} \mathrm{Ar}$, where Ar* denotes the air-free Ar concentration of the sample and ${ }^{36} \mathrm{Ar}$ is

assumed to be entirely atmospheric. The endmembers at high ${ }^{40} \mathrm{Ar} /{ }^{36} \mathrm{Ar}$ ratios displayed $\mathrm{Ar} *$ contents which markedly differed among the sites, moving in a range of more than two orders of magnitude: 2-60 ppm at St, 30-70 ppm at P39, 20-160 ppm at VS and 200-900 ppm at Fd. These differences in the Ar* content were opposite to those of $\mathrm{CO}_{2}$, that ranged from $0.2-0.7 \mathrm{~mol} \%$ of $\mathrm{Fd}$ up to $90-98 \mathrm{~mol} \%$ of St. Hence, the $\mathrm{Ar} * / \mathrm{CO}_{2}$ ratios of the sampling sites were spread over a range 
of more than four orders of magnitude (Fig. 3a). Such a large differences among the peripheral sites were also observed in the values of $\mathrm{He} / \mathrm{CO}_{2}$ ratios (Fig. 3b), due to changes by about two orders of magnitude in He concentrations, coupled to other two orders of magnitude for $\mathrm{CO}_{2}$. Inspection of Figures $3 \mathrm{a}$ and $3 \mathrm{~b}$ strongly suggests that the $\mathrm{He} / \mathrm{CO}_{2}$ and $\mathrm{Ar} * / \mathrm{CO}_{2}$ ratios are both controlled by the same process.

Caracausi et al. (2003b) recognized that selective dissolution into aquifers can markedly change the concentration of noble gases in $\mathrm{CO}_{2}$-dominated gas mixtures, and they modeled the $\mathrm{He} / \mathrm{CO}_{2}$ ratio of the peripheral emissions using such a dissolution-driven process. Starting from a pristine gas with low $\mathrm{He} / \mathrm{CO}_{2}$ ratio, the latter increases by preferential dissolution of $\mathrm{CO}_{2}$ than $\mathrm{He}$, so as to fit the compositions at all of the sites (Fig. 3b). Here we included Ar in their model of dissolution, with the aim of calculating the paths of gas fractionation (see caption of Fig. 3b). The calculated path perfectly fit the composition of all of the peripheral gas discharges over four orders of magnitude of $\mathrm{Ar}^{*} / \mathrm{CO}_{2}$ variation.

Following the approach of Caracausi et al. (2003b), we corrected both $\mathrm{He} / \mathrm{CO}_{2}$ and $\mathrm{Ar} * / \mathrm{CO}_{2}$ ratios of each gas sample for the effects of dissolution-driven fractionation in hot aquifers. For each data point of Fig. 3, this required (i) selecting suitable values of initial $\mathrm{CO}_{2}$ concentration, $\mathrm{He} / \mathrm{CO}_{2}$, and $\mathrm{Ar}^{*} / \mathrm{CO}_{2}$ ratios of the dissolution model (namely, the values in the gas phase prior to interaction with the aquifers), and (ii) computing a model curve that matches the given data point by starting from the selected initial conditions. The initial $\mathrm{CO}_{2}$ concentration can be constrained using the reasonable assumption that the incondensable fraction of magmatic gases is largely dominated by $\mathrm{CO}_{2}\left(>98 \mathrm{~mol} \%\right.$, the remaining part being $\mathrm{CH}_{4}$ and $\mathrm{N}_{2}$ ). With this constraint, the initial $\mathrm{He} / \mathrm{CO}_{2}$ and $\mathrm{Ar} * / \mathrm{CO}_{2}$ values were tentatively changed until the dissolution path matched the selected data point. The achieved initial ratios were taken as the restored ratios for that data point. They could be considered the ratios of the pristine magmatic gas of that sample prior to the interaction with the aquifers. We computed only trivial variations of the He/Ar* ratio throughout the dissolution process due to the very low solubilities of $\mathrm{He}$ and $\mathrm{Ar}$ relative to $\mathrm{CO}_{2}$ in hot water. Even at $\mathrm{Fd}$, which 
suffered from the greatest loss of $\mathrm{CO}_{2}$ by dissolution $\left(\mathrm{CO}_{2}<0.5 \mathrm{~mol} \%\right.$ in the emitted gas), we computed that the He/Ar* value of the residual gas mixture decreased by less than $20 \%$ during the selective dissolution in water, whereas the calculated changes were lower than $10 \%$ at all of the other sites.

The inferences from the Ar survey also provided strong constraints for the Ne geochemistry. A suitable Ne correction for air would in fact require knowledge of the Ne-isotope composition, which was not yet available. During periods of high volcanic activity (e.g., 2001 to 2003), air contamination in the gas vents was generally less important, as shown by the high $\mathrm{He} / \mathrm{Ne}$ ratios in Figure 4. Accordingly, the $\mathrm{He} / \mathrm{CO}_{2}$ ratio that had been corrected for dissolution displayed synchronous increases relative to $\mathrm{He} / \mathrm{Ne}$, whereas the former had to be constant or anticorrelated in the case of air-induced variations of $\mathrm{He} / \mathrm{Ne}$ (Caracausi et al., 2003b). However, the ${ }^{40} \mathrm{Ar} /{ }^{36} \mathrm{Ar}$ ratios during the period investigated in this paper (2005 to 2010) suggested a significant air contribution (see above) that prevented the use of the $\mathrm{He} / \mathrm{Ne}$ ratios as direct magmatic markers. In fact, after 2005 we observed no further covariations between $\mathrm{He} / \mathrm{Ne}$ and $\mathrm{He} / \mathrm{CO}_{2}$ (or $\mathrm{He} / \mathrm{Ar} *$ ) values that had been corrected for dissolution.

\subsection{Voragine crater fumaroles}

The survey of summit crater fumaroles revealed Ar contents ranging from less than 10 ppm up to the typical air concentration (i.e. 9300 ppm). The Ar isotopic composition changed accordingly, indicating the presence of binary mixing between atmosphere and an Ar-poor endmember with high ${ }^{40} \mathrm{Ar} /{ }^{36} \mathrm{Ar}$ ratios (low ${ }^{36} \mathrm{Ar} /{ }^{40} \mathrm{Ar}$, see Fig. 2). Samples collected at the crater on the same day normally fall along a single mixing line. Therefore, a single Ar* value could be estimated and the air fraction consequently calculated for each sampling date by performing a best fit to the data with the mixing line. The calculated endmembers can be found in Table 1 of the supplementary material.

The Ar* values of crater fumaroles varied slightly over time, but remained at around a few ppm and were therefore substantially lower than those at the peripheral sites. This was most likely due to 
the very small dissolution-driven fractionation of the incondensable gas species affecting crater fumaroles relative to the peripheral vents. The interaction of magma vapors with high-temperature hydrothermal solutions has been found to scrub no more than $40 \%$ of the magmatic $\mathrm{CO}_{2}$ feeding the fumaroles (Liotta et al., 2010). The He/Ar* ratios were virtually unaffected by this scrubbing process, and even the $\mathrm{He} / \mathrm{CO}_{2}$ and $\mathrm{Ar} * / \mathrm{CO}_{2}$ ratios increased by $30-40 \%$ or less (Fig. 5). Anyway, these fractionations were negligible compared to the orders-of-magnitude enrichments at the peripheral sites due to $\mathrm{CO}_{2}$ dissolution in aquifers, and cannot be appreciated in Figure 3 . Consequently, the crater fumaroles in Figure $3 \mathrm{a}$ fall close to the starting point of the fractionation path, where the pristine magmatic gas has still not interacted with groundwater.

The air fraction of each fumarole sample, calculated using Ar data, was applied to correct the measured $\delta^{13} \mathrm{C}_{\mathrm{CO} 2}$ values; however, the corrections were negligible due to the low $\mathrm{CO}_{2}$ content in air (about $390 \mathrm{ppm}$ ). There were always only very small differences in $\delta^{13} \mathrm{C}_{\mathrm{CO} 2}$ among crater fumaroles sampled on the same date (in general, within the analytical uncertainty; Table 1 of supplementary material), and they were clearly lower than the variations over time. Similarly, the He-isotope compositions were comparable for the fumaroles sampled on the same date, whilst the $\mathrm{R} / \mathrm{Ra}$ variations over time were much larger (except for the most-air-contaminated samples with $\mathrm{He} / \mathrm{Ne}<20$; see Table 1 of supplementary material). We preferred to use the He/Ne ratio rather than ${ }^{40} \mathrm{Ar} /{ }^{36} \mathrm{Ar}$ to correct $\mathrm{R} / \mathrm{Ra}$ for the addition of air, because both $\mathrm{R} / \mathrm{Ra}$ and $\mathrm{He} / \mathrm{Ne}$ were simultaneously measured during a single mass spectrometer analysis. As for Ar, the data obtained at the same time were fitted by a single mixing curve in a plot of $\mathrm{R} / \mathrm{Ra}$ versus $\mathrm{He} / \mathrm{Ne}$, so we estimated a single $\mathrm{R} / \mathrm{Ra}$ value of the not-atmospheric endmember for each sampling date (see Table 1 of supplementary material).

\section{MAGMATIC GASES IN THE He-Ar-CO$-\mathrm{O}_{2}-\delta^{13} \mathrm{C}_{\mathrm{CO} 2} \mathrm{SYSTEM}$}

Once we had removed the effects caused by the postmagmatic processes we were able to focus on the pristine magmatic signatures of the Etnean gases. Hereafter we will deal with the elemental or 
isotope ratios of peripheral vents corrected for both air contamination and aquifer interaction. In the case of crater fumaroles, we will use the magma endmember values as computed in Section 4.

The covered range of He/Ar* ratios was similar for all vents (0.5 to 6) and included the typical production ratios of MORB mantle (2 to 4; Graham, 2002). In the two-ratio diagram of He/Ar* versus $\mathrm{Ar}^{*} / \mathrm{CO}_{2}$ in Figure 6, the Etnean data exhibit a main trend that includes the peripheral sites plus the crater fumaroles. We recall that the $\mathrm{Ar} * / \mathrm{CO}_{2}$ ratios at $\mathrm{St}, \mathrm{P} 39$, VS, and Fd have been heavily corrected for groundwater interaction, whilst the crater fumaroles required corrections by less than $40 \%$, which are small in the bilogarithm plot in Figure 6 (i.e., within the error bars). The alignment between fumaroles and peripheral sites thus supports the reliability of our modeling of the postmagmatic processes.

Figure 6 shows a very strong negative correlation between the two ratios. Similar trends have been attributed to processes of magma degassing (Paonita and Martelli, 2007), with the negative slope resulting from the differences in solubility between the three species in basaltic melts $\left(\mathrm{He}>\mathrm{CO}_{2}>>\mathrm{Ar}\right.$; Iacono-Marziano et al., 2010). Magma degassing theoretically affects also the carbon-isotope composition of the released vapor. The experimental data for basaltic melts indicated that $\mathrm{CO}_{2}$ with higher mass number is preferentially exsolved from the melt, with a vapormelt enrichment factor $\left(\varepsilon_{\text {vap-melt }}\right)$ ranging from $+2 \%$ to $+4 \%$ (Javoy et al., 1978; Mattey, 1991; Trull et al., 1992). Measurements of $\delta^{13} \mathrm{C}_{\mathrm{CO} 2}$ in vesicles and glasses of MORB products have suggested

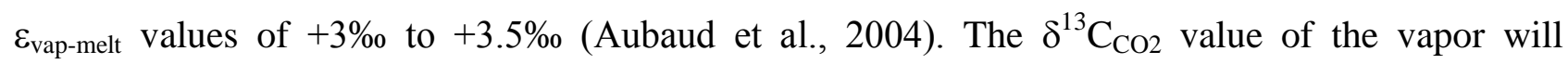
therefore be maximal early during exsolution and then progressively decrease during degassing. On this basis we could guess that there is an inverse relationship between $\delta^{13} \mathrm{C}_{\mathrm{CO} 2}$ and $\mathrm{He} / \mathrm{Ar}$ (or a direct one between $\delta^{13} \mathrm{C}_{\mathrm{CO} 2}$ and $\mathrm{Ar} * / \mathrm{CO}_{2}$ ) for crater fumaroles, given that neither $\mathrm{He} / \mathrm{Ar} *$ nor $\delta^{13} \mathrm{C}_{\mathrm{CO} 2}$ are affected by the local hydrothermal interaction. However, the plot of $\delta^{13} \mathrm{C}_{\mathrm{CO} 2}$ versus He/Ar* for crater fumaroles in Figure 7 shows no clear relation, and hence processes other than simple open-system degassing probably control fluid geochemistry of Mt Etna magmatic gases. 


\section{MODEL OF MAGMA DEGASSING}

Investigating magma degassing in the $\mathrm{He}-\mathrm{Ar}-\mathrm{CO}_{2}-\delta^{13} \mathrm{C}_{\mathrm{CO} 2}$ system requires a suitable quantitative tool. We implemented the refined model of isothermal decompressive degassing of $\mathrm{H}_{2} \mathrm{O}-\mathrm{CO}_{2}-\mathrm{He}-$ Ne mixtures developed by Caracausi et al. (2003b) for Etnean basalt melts. The initial and boundary conditions of that model were constrained based on studies of the historical products of Mt Etna (pre-Etnean hyaloclastites; erupted volcanites in the period from 1600 to 1800 a.c.) as follows: (i) $\mathrm{CO}_{2}$ contents and the entrapment pressure of fluid inclusions in primitive olivines (Clocchiatti et al., 1992; Kamenetsky and Clocchiatti, 1996), and (ii) the $\mathrm{H}_{2} \mathrm{O}$ contents and homogenization temperature of primitive melt inclusions (Metrich et al., 1993; Kamenetsky and Clocchiatti, 1996). However, recent Etnean activity (particularly the 2001 and 2002/2003 eruptions) was more basic, richer in volatiles, and showed the occasional occurrence of amphibole and orthopyroxene (Clocchiatti et al., 2004; Corsaro et al., 2007). The $\mathrm{H}_{2} \mathrm{O}$ and $\mathrm{CO}_{2}$ contents in olivine-hosted melt inclusions from the Mt Etna eruptions between 2001 and 2006 reached $3.5 \mathrm{wt} \%$ and 3500 ppm, respectively, indicating entrapment pressures of up to $450 \mathrm{MPa}$ (Clocchiatti et al., 2004; Metrich et al., 2004; Spilliaert et al., 2006; Collins et al., 2009). The crystallization temperature of the melts at high pressure was estimated to be $\sim 1150^{\circ} \mathrm{C}$ (Corsaro et al., 2007). Based on the $\mathrm{H}_{2} \mathrm{O}-\mathrm{CO}_{2}$ saturation surface of Etnean basalts (Papale et al., 2006), we calculated that the earliest exsolved vapor phase at $450 \mathrm{MPa}$ and $1150^{\circ} \mathrm{C}$ consisted of $\sim 75 \mathrm{~mol} \% \mathrm{CO}_{2}$. We selected these new thermobaric and compositional constraints as the initial conditions of the model.

Ar was added as a further gas species to the model of Caracausi et al. (2003b). We used the general equations given by Nuccio and Paonita (2001), which require suitable Ar solubility value in the silicate melt. To account for the effect of dissolved $\mathrm{H}_{2} \mathrm{O}$ on Ar solubility, the latter was computed using the model of Nuccio and Paonita (2000) with recalibration using experimental data for anhydrous (Iacono-Marziano et al., 2010) and hydrous basaltic melts of Mt Etna (see the Appendix). 
We also needed to select two $\mathrm{He} / \mathrm{Ar} *$ and $\mathrm{Ar} * / \mathrm{CO}_{2}$ values as a starting point for the degassing simulation. Due to the relations among $\mathrm{He}, \mathrm{Ar}$, and $\mathrm{CO}_{2}$ solubilities, the first vapor that separates from magma display the lowest $\mathrm{He} / \mathrm{Ar}^{*}$ value and the highest $\mathrm{Ar} * / \mathrm{CO}_{2}$ value of the degassing path. Therefore, the lowest He/Ar* measured in the peripheral vents $(\sim 0.4)$ represented a maximum value of the initial vapor, because the degassing path could start from still lower values. To constrain our choice, we used the He/Ar* ratios measured in olivine-hosted fluid inclusions of recent Mt Etna eruptions (2.1 \pm 0.5 ; Nuccio et al., 2008), which were derived from bulk crushing of hundreds of olivine crystals with various extents of evolution and thus are likely to represent the average value of the magmatic system. Based on the He/Ar solubility ratio ( 10; see Iacono-Marziano et al., 2010 and Appendix), an $\mathrm{He} / \mathrm{Ar}^{*}$ ratio of the whole system of around 2 implies that the first exsolved vapor will have an $\mathrm{He} / \mathrm{Ar}^{*}$ ratio close to 0.2 , which is only slightly lower than the lowest $\mathrm{He} / \mathrm{Ar} *$ measured at the peripheral vents. We therefore selected an $\mathrm{He} / \mathrm{Ar}^{*}$ equal to 0.2 as the initial value and computed that any changes in this value within the range given for the fluid inclusions would introduce uncertainties of about $\pm 15 \mathrm{MPa}$ in the estimated pressures. Once the initial $\mathrm{He} / \mathrm{Ar}^{*}$ had been selected, the $\mathrm{Ar} * / \mathrm{CO}_{2}$ could be accordingly constrained to fit the main trend in Figure 6 .

The final step was implementing the model for carbon isotopes. The isotope mass balance among total, dissolved, and exsolved $\mathrm{CO}_{2}$ controls the exsolution process provided that the isotopic enrichment factor between gaseous and dissolved $\mathrm{CO}_{2}$ is available. Available data for basaltic melts indicate that $\varepsilon_{\text {vap-melt }}$ is between $+2 \%$ and $+4 \%$ (see Section 5 ), and hence we used $+3 \%$; in Section 7.1 we discuss the effects of uncertainties in $\varepsilon_{\text {vap-melt }}$ on our results. An initial (the first separated vapor) or whole-system (vapor+melt) value of $\delta^{13} \mathrm{C}_{\mathrm{CO} 2}$ was also required to compute the isotope degassing path, but this is not currently available from studies of Etnean melt or fluid inclusions. Typical mantle values ( $-4 \%$ o to $-6 \%$; Cartigny et al., 2001) have ranges that are too large for them to be used as a constraint, and could be inappropriate for the Etnean magma source given the possible occurrence of carbonate assimilation and/or mantle metasomatism. Consequently, we did 
not select the $\delta^{13} \mathrm{C}_{\mathrm{CO} 2}$ value as a boundary condition of our model, instead leaving this parameter as a free variable to fit the fumarolic data.

\section{RESULTS}

Starting from the selected initial and boundary conditions, we simulated the decompressive isothermal degassing of the Etnean basalt magma. In Figure 8a,b it is evident that both $\mathrm{He} / \mathrm{Ar}$ and $\mathrm{He} / \mathrm{CO}_{2}$ increased while both $\mathrm{Ar} / \mathrm{CO}_{2}$ and $\delta^{13} \mathrm{C}_{\mathrm{CO} 2}$ decreased as the degassing pressure increased.

The results of our degassing calculations plotted in Figure 6 clearly indicate that the path of open-system degassing starting from an initial pressure of $450 \mathrm{MPa}$ (the curve labeled " $\mathrm{P}{ }^{\circ}=450$ $\mathrm{MPa}$, open" in the figure) provided a very good fit to the trend depicted by our data. In contrast, the path of closed-system degassing (the curve labeled " $\mathrm{P}^{\circ}=450 \mathrm{MPa}$, closed") did not describe the coupled $\mathrm{He} / \mathrm{Ar} *$ and $\mathrm{Ar} * / \mathrm{CO}_{2}$ changes. A calculated path starting from initial pressures lower than $300 \mathrm{MPa}$ (the curve labeled " $\mathrm{P}^{\circ}=300 \mathrm{MPa}$, open" in Fig. 6) provided a significantly less accurate fit to the data trend, due to the curve bend occurring already at intermediate extents of degassing.

The measured range of He/Ar* values at the peripheral sites seems to be due to the exsolution of magmatic fluids at pressures of 380 to $230 \mathrm{MPa}$ (Fig. 8a), in agreement with previous results by Caracausi et al. (2003b), who identified the transfer of magma batches from 400 to $200 \mathrm{MPa}$ via $\mathrm{He} / \mathrm{Ne}$ variations in the same gas emissions. Among the peripheral sites, P39 shows the narrowest range of exsolution pressures (370 to $290 \mathrm{MPa}$; see main plot in Fig. 6), indicating that it only receives gases from the deepest portions of the system. In contrast, the exsolution pressures of the crater fumaroles, estimated by their He/Ar* values, appear to range between 280 and $210 \mathrm{MPa}$ (Figs. 6 and 8a), suggesting that the crater fumaroles on average sample shallower portions of the magmatic system than do the peripheral vents. However, in the next section we show that caution is necessary when establishing a direct relation between chemical ratios (i.e., He/Ar*) and the exsolution pressure. 
Finally, the $\delta^{13} \mathrm{C}_{\mathrm{CO} 2}$ values of crater fumaroles did not display any apparent simple relation with an unambiguous indicator of degassing, such as the He/Ar* ratio, and they did not appear to agree with the computed path of magmatic degassing (Fig. 7).

\subsection{Mixing between gases exsolved at different pressures}

As mentioned in Section 1, geophysical studies have described the Etnean plumbing system in the form of interconnected dikes and sills, rather than as a chamber-like reservoir (Hirn et al., 1997; Chiarabba et al., 2000; De Gori et al., 2005; Aloisi et al., 2009). Such a structure strongly favors mechanisms of bubble segregation in dikes, similar to those investigated experimentally by Menand and Phillips (2007). Our evidence of open-system degassing is consistent with this framework, since it implies efficient gas-melt decoupling at depth. When vapors separate from the magma at great depth, they convectively migrate toward the surface and can mix with magmatic gases degassed at shallower levels. We now quantitatively explore this hypothesis by considering the compositional balances between two vapors coming from two different depths along the same degassing path.

Based on the measured He/Ar* values at the investigated sites, we already inferred that the pressure at the deepest portion of the magmatic system feeding the emissions was about $400 \mathrm{MPa}$ (Figs. 6 and 8a). Once this pressure (400 MPa) and the composition of this high-pressure gas (in terms of $\mathrm{He} / \mathrm{Ar}, \mathrm{Ar} / \mathrm{CO}_{2}$, and $\delta^{13} \mathrm{C}_{\mathrm{CO} 2}$ values) were fixed, the shape of a typical mixing curve with another gas released at lower pressure (with higher $\mathrm{He} / \mathrm{Ar}$ and lower $\mathrm{Ar} / \mathrm{CO}_{2}$ and $\delta^{13} \mathrm{C}_{\mathrm{CO} 2}$ ) depended on the degassing pressure of the latter fluid. Due to the $\mathrm{Ar}<<\mathrm{He}<\mathrm{CO}_{2}$ solubility relation, the $\mathrm{He} / \mathrm{Ar}$ ratio exhibited variations similar to those of $\mathrm{Ar} / \mathrm{CO}_{2}$ (but with opposite sign) during decompressive open-system degassing, typically down to pressures of 130-160 MPa (inset of Fig. 6). Below 130 $\mathrm{MPa}$, the $\mathrm{He} / \mathrm{Ar}$ ratio changed more quickly than did $\mathrm{Ar} / \mathrm{CO}_{2}$, thereby causing a bend of the degassing path in Figure 6. Under the condition that the low-pressure endmember did not exsolve at pressures lower than $160 \mathrm{MPa}$, its addition to an high-pressure (400 $\mathrm{MPa}$ ) exsolved gas would 
cause similar variations of both $\mathrm{He} / \mathrm{Ar}$ and $\mathrm{Ar} / \mathrm{CO}_{2}$ (although having opposite sign), so as to give a nearly straight mixing line close to the degassing path (see the curve labeled "mixing 400 to 130 " in Fig. 6). In contrast, the mixing of a deep gas with a shallow endmember exsolved at lower than $130 \mathrm{MPa}$ would produce a path that differs significantly from the degassing one (see the curve labeled "mixing 400 to 100 " in Fig. 6). In practice, a lower exsolution pressure would produce larger differences.

The comparison between the computed mixing curves and the field data in Figure 6 shows that the mixing line between 400- and 130-MPa exsolved fluids is very close to most of the crater and peripheral compositions and, together with the open-system degassing path, it encompasses all of our data (within their uncertainties). Therefore, we obtained the intriguing result that the composition of the sampled vents was effectively compatible with a mixing process between fluids exsolved at different pressures (depths) along an open-system degassing path. We constrained the exsolution of the shallow endmember at pressures higher than $130 \mathrm{MPa}$, since at lower pressures the mixing line would drift away from the data (Fig. 6) and the percentages of the shallow endmember in the fumarole gases would essentially become trivial.

The subsequent step consisted of calculating the effects of the mixing on the carbon-isotope signature of the magma gases. Let us focus on the most probable case of mixing selected before; namely the addition of a 400-MPa exsolved fluid to a shallow fluid degassed at $130 \mathrm{MPa}$. We first consider the isotope variations during magma degassing in order to constrain the compositional differences between the two endmembers. Figure 8 provides evidence that the degassing-driven changes in $\delta^{13} \mathrm{C}_{\mathrm{CO} 2}$ were much smaller than those in He/Ar: open-system decompression from 400 to $130 \mathrm{MPa}$ increased $\mathrm{He} / \mathrm{Ar}$ by about 100 -fold, due to the dramatic Ar loss, whereas $\delta^{13} \mathrm{C}_{\mathrm{CO} 2}$ decreased by less than 5 -fold. The result is a strongly bent degassing path in a plot of $\delta^{13} \mathrm{C}_{\mathrm{CO} 2}$ versus $\mathrm{He} / \mathrm{Ar}$ (Fig. 7). The same decompression also caused a moderate decrease in the $\mathrm{CO}_{2}$ concentration in the exsolved gas (from 72 to 43 mol\%; data not shown). Thus, the high-pressure gas will display moderately higher $\delta^{13} \mathrm{C}_{\mathrm{CO} 2}, \mathrm{CO}_{2}$, and He values, but orders-of-magnitude higher $\mathrm{Ar}$ 
contents, with respect to the low-pressure gas. As a result, He/Ar of the high-pressure endmember would be practically unmodified by the addition of up to $50 \%$ of the low-pressure gas, whilst the $\delta^{13} \mathrm{C}_{\mathrm{CO} 2}$ value of the $50 \%$ mixture would fall almost halfway between the two endmembers (see the inset in Fig. 7). This explains the strong concavity of the mixing curve.

We can now compare in Figure 7 our crater data with the computed mixing line between vapors exsolved at 400 and $130 \mathrm{MPa}$ [hereafter named the extreme mixing line (EML)]. We recall that the initial $\delta^{13} \mathrm{C}_{\mathrm{CO} 2}$ of vapor in the magma system is a free parameter; that is, both the degassing and mixing paths of Figure 7 can be vertically shifted by the same amount in order to fit our field data. When the initial $\delta^{13} \mathrm{C}_{\mathrm{CO} 2}$ is selected as $+1.9 \%$ (namely $\delta^{13} \mathrm{C}_{\mathrm{CO} 2}=-1.1 \%$ or the whole system, with $\varepsilon_{\text {vap-melt }}=+3 \%$ ), all of the fumarolic data fall in the area enclosed between the degassing path and the EML, with several points falling very close to the latter (Fig. 7).

We conclude that the $\mathrm{He} / \mathrm{Ar} *$ and $\mathrm{Ar} * / \mathrm{CO}_{2}$ ratios and the $\delta^{13} \mathrm{C}_{\mathrm{CO} 2}$ data are compatible with the coupled degassing-mixing process, in which two fluids that were exsolved at different pressures (depths) along an open-system degassing path mixed together. A combined evaluation of the three parameters results in the definite rejection of the hypothesis that the low-pressure endmember was exsolved at a pressure lower than $130 \mathrm{MPa}$. In fact, when selecting $100 \mathrm{MPa}$ for the shallow term, the mixing line remains very close to the data in Figure 7 (see the inset), while Figure 6 already shows the dramatic drift far from the crater data.

\subsection{Changes in mixing fraction versus endmember pressure}

Particular data obtained from the crater fumaroles highlight the coherency of the coupled degassingmixing process in explaining the chemical and isotope measurements. The sample of July 8, 2009 (with the highest He/Ar*) falls close to the pure degassing curve in both Figures 6 and 7, whereas the sample of September 22, 2010 (with the lowest He/Ar*) matches the EML, at about 25\% of the deep endmember. 
Moreover, during the period from August 18, 2008 to June 29, 2009 we recorded a dramatic decrease in $\delta^{13} \mathrm{C}_{\mathrm{CO} 2}$ values, followed by an increase back to the initial values (Fig. 9). These changes were associated with opposite variations of $\mathrm{He} / \mathrm{Ar}^{*}$, so that this group of data approximately moves along the EML (Fig. 7). These compositional variations can be accounted for by simple changes in the mixing fraction between deep and shallow endmembers. It should be noted that the decrease in $\delta^{13} \mathrm{C}_{\mathrm{CO} 2}$ - which implies an increase in the mixing proportions of the shallow vapor-was also accompanied by decreasing values of the He-isotope ratios in the crater emissions (Fig. 9). We recall that deep parental magmas normally have higher $\mathrm{R} / \mathrm{Ra}$ ratios than resident magmas because all en-route processes such as crustal contamination, assimilation, and magma aging can only lower the ratio (Hilton et al., 2000). On this basis, the direct relation between $\delta^{13} \mathrm{C}_{\mathrm{CO} 2}$ and $\mathrm{R} / \mathrm{Ra}$ is qualitatively in agreement with the mixing process.

On the other hand, most data points are located halfway between the EML and the degassing path in Figure 7, and could be fitted by mixing lines that are closer to the degassing line than the EML. With this in mind, we show in Figure 7 the mixing lines calculated with the high-pressure endmember exsolved at progressively lower pressures than $400 \mathrm{MPa}$ (recall that 400 and $130 \mathrm{MPa}$ are the two endmember pressures for the EML). As expected, when the exsolution pressure decreases from 400 to $200 \mathrm{MPa}$, the mixing lines progressively approach the degassing path and, as a consequence, they match the midway data points. Figure 7 shows how the grid of the mixing curves calculated in this way is able to perfectly explain the complete dataset.

If we now focus on the period from July 17, 2007 to May 5, 2008, when an almost constant $\delta^{13} \mathrm{C}_{\mathrm{CO} 2}(\sim-1.5 \%$ ) was associated with a general variation in $\mathrm{He} / \mathrm{Ar} *$ from 4 to 2.5 (Fig. 7$)$. While the early data of the period (with $\mathrm{He} / \mathrm{Ar}^{*} \approx 4$ ) are close to the mixing curve between 250 - and 130$\mathrm{MPa}$ endmembers, the later data (with He/Ar* $\approx 1.5$ ) match the 350-130 MPa mixing line, thereby involving a relevant increase in the exsolution pressure of the deep endmember. A different hypothesis for explaining the emphasized variation of He/Ar* would be as follows (although we do not add the related curves to Fig. 7 for sake of clarity): we start from a mixing line between 400- 
and $200-\mathrm{MPa}$ endmembers that matches the data with $\mathrm{He} / \mathrm{Ar}^{*} \approx 4$, and suppose that the exsolution pressure of the shallow endmember decreases from $200 \mathrm{MPa}$ to about $150 \mathrm{MPa}$ in order to explain the data with $\mathrm{He} / \mathrm{Ar}^{*} \approx 1.5$. Nevertheless we believe it poorly probable. In fact, it is noteworthy that the investigated variations preceded a major eruptive event starting in May 2008 and lasting about 1 year, and were also characterized by a dramatic increase in the R/Ra ratio (Fig. 9). Because it is reasonable to link high $\mathrm{R} / \mathrm{Ra}$ values with deep primitive magmas (see above), it is logical to suppose that the He/Ar* ratios decreased due to an increasing contribution from such magmas. Accordingly, consideration of petrology, mineral chemistry, $\mathrm{Sr}$ and $\mathrm{Nd}$ isotopes, and major and trace elements of volcanites that erupted during the fire fountains on March 29 and September 4, 2007 revealed the arrival of more primitive magmas into the system (Corsaro and Miraglia, 2009). In our opinion, all of these features strongly support the hypothesis that the geochemical variations were caused by an increasing exsolution pressure of the deep endmember.

On July 8, 2009, which was several weeks after the end of the 2008/2009 eruption, there was a sharp peak in both $\delta^{13} \mathrm{C}_{\mathrm{CO} 2}$ (Fig. 9) and $\mathrm{He} / \mathrm{Ar}^{*}$, which moved the fumarole gases close to the degassing curve in Figure 7. This means that magmatic gases arrived exclusively from shallow levels of the magma system (no more than $210 \mathrm{MPa}$ ), with no appreciable contribution from greater depths. Consistent with previous outcomes, the R/Ra values dropped by about 0.2 units due to lack of the high-R/Ra contribution from the deep fluids (Fig. 9).

\section{FINAL REMARKS, AND INFERENCES ABOUT THE PLUMBING SYSTEM}

We have carried out a 4-year geochemical survey of some fumaroles at the Voragine summit crater of Mt Etna, combined with synchronous monitoring of some well-known peripheral gas emissions. We measured the isotope abundances of $\mathrm{Ar}, \mathrm{He}$, and $\mathrm{CO}_{2}$, as well as the chemical compositions of the gases. Once the effects of postmagmatic shallow processes had been identified, quantified, and removed, the geochemistry of the crater fumaroles and peripheral vents revealed clear genetic relations between these two groups of emissions discharged at very different elevations of the 
volcano. Our study has revealed that the summit crater fumaroles are aligned along the identical degassing path at the peripheral sites in terms of $\mathrm{He} / \mathrm{Ar} *$ versus $\mathrm{Ar} * / \mathrm{CO}_{2}$ ratios, with the fumarole gases exsolving at average pressures that are lower than those for peripheral vents. Interestingly, the carbon-isotope composition of the fumaroles, combined with the observations of the noble gases, provide evidence that part of the exsolved magmatic gases at great depths interact with gases from magma batches stored at shallow levels and thereby modify the compositional ratios of the main geochemical indicators of magma degassing. This results in the abundance ratios (i.e., He/Ar*) are no more univocally linked to the exsolution pressure, and hence they have to be interpreted cautiously. The crater fumaroles indeed result from a two-endmember mixture of magmatic gases, composed of a deep endmember coming from variable pressures of 400 to $200 \mathrm{MPa}$ depending on time, and a shallower one exsolved at about $130 \mathrm{MPa}$.

It is worthy to note that our mixing model does not require that a deep vapor directly enters a shallow magma batch, but it more simply involves two exsolved magmatic fluids after they have left their respective magma bodies. On the other hand, significant enrichments of $\mathrm{CO}_{2}$ and fluid mobile elements in melt inclusions and rocks of Mt Etna have suggested the direct interaction of deep gases with magma-gas mixtures stored at shallower levels (Metrich et al., 2004; Ferlito et al., 2007; Collins et at., 2009; Ferlito and Lanzafame, 2010). Although different, our model and these views do not necessarily contrast. In fact, whereas a part of exsolved gases at depth can mix with shallow gases and feed fumaroles, another part could percolate through a shallow magma reservoir. Gases feeding fumaroles can therefore record different processes with respect to volatiles entrapped in volcanites. Obviously, the direct percolation of gases through magma and their subsequent outgassing would require a totally different approach, which should also consider possible kinetic effects due to volatile diffusion from and into melt (see Yoshimura and Nakamura, 2011), however our present dataset does not show evidences of this process.

The measured $\delta^{13} \mathrm{C}_{\mathrm{CO} 2}$ and $\mathrm{He} / \mathrm{Ar}^{*}$ values of fumaroles show patterns of temporal variation, with at least two distinct cases being identifiable: (i) coupled changes in $\delta^{13} \mathrm{C}_{\mathrm{CO} 2}$ and $\mathrm{He} / \mathrm{Ar}$, which 
are due to variations in the mixing proportions of the two endmembers, and (ii) a decrease in $\mathrm{He} / \mathrm{Ar}^{*}$ associated with almost constant $\delta^{13} \mathrm{C}_{\mathrm{CO} 2}$ values, implying compositional variations of the deep endmember caused by an increase in its pressure of exsolution. From July 17, 2007 to May 22, 2008 , the increase in the exsolution pressure accompanied the escalation of volcanic activity that preceded the 2008/2009 eruption. Pressure variations due to deep magma recharges could thus destabilize the magmatic system. Such conditions would typically result in the system exhibiting nonlinear dynamics (Sparks, 2003), which would explain the strong nonlinear signatures recently revealed in the R/Ra time series of Etnean gas vents (Paonita, 2010).

Our estimated $\delta^{13} \mathrm{C}_{\mathrm{CO} 2}$ values of the magma system ( -1\%0), which are far from the mantle range ( $-4 \%$ to $-6 \%$; Cartigny et al., 2001), strongly suggest that metasomatic processes had affected the C-isotope marker in the mantle source and/or in the deep plumbing system. Indeed, the Etnean mantle could be affected by an increasing contribution from a subduction-like component (Schiano et al., 2001; Tonarini et al., 2001), or it could be regarded as a heterogeneous source carrying the fingerprint of fossil metasomatism (Viccaro and Cristofolini, 2008; Viccaro et al., 2011). The assimilation of carbonate rocks belonging to the sedimentary basement is a further possible mechanism affecting $\mathrm{C}$ isotopes. This process has been already identified at Mt Vesuvius and other volcanoes in Central Italy on the basis of petrological constraints (Iacono-Marziano et al., 2009), and it has also been proposed that it occurs at Mt Etna (Chiodini et al., 2010). Future petrological studies will have to quantify the effective degree of carbonate assimilation experienced by Mt Etna magmas.

Our results help constraining the internal structure of the Etnean plumbing system. The coupled degassing-mixing process is indicative of efficient decoupling of bubbles from melt, so that segregated fluids can ascend and mix with magmatic gases exsolved at shallower levels. This points to a system composed of horizontally elongated and dike-like structures that inhibit magma ascent. By assuming a magma density of $2.7 \mathrm{~g} / \mathrm{cm}^{3}$ for Etnean basalt, the pressure interval given for the deep endmember matches a depth range of 5 to $12 \mathrm{~km}$ b.s.l. At these depths, the plumbing system 
would consist of the entirely crystallized main intrusive body, plus small volumes of melts (Chiarabba et al., 2000; Laigle et al., 2000). Investigations of the seismic tomography have also recently identified a vertically elongated zone of P-wave attenuation, which would be the main pathway via which magmas ascend from their source to shallower levels (De Gori et al., 2005). Based on our results, such a pathway would consist of small horizontal structures linked by vertical connections, and these would allow vapor exsolution and bubble separation from a large range of pressures/depths.

Finally, the pressure-to-depth conversion for the shallow endmember identifies an exsolution level at about $2 \mathrm{~km}$ b.s.l., in agreement with the results from GPS and microgravity data (Bonaccorso and Davis, 2004; Budetta et al., 2004; Mattia et al., 2007), seismic tomography (De Gori et al., 2005), and magma buoyancy studies (Corsaro and Pompilio, 2004), which place a main reservoir of magma at $\sim 3.0 \pm 1.5 \mathrm{~km}$ b.s.l. Our data thus suggest that this reservoir would be a main structure of vapor segregation from melt and that its gas contribution would enduringly feed the fumaroles.

\section{Acknowledgments}

The Authors wish to thank two anonymous reviewers for their helpful comments and their appreciation of this work. Discussions with M. Liotta about fluid circulation at Mt Etna summit were also very valuable. 


\section{References}

Aiuppa A., Moretti R., Federico C., Giudice G., Gurrieri S., Liuzzo M., Papale P., Shinohara H. and Valenza M. (2007) Forecasting Etna eruptions by real-time observation of volcanic gas composition. Geology, 35(12), 1115-1118, doi:10.1130/G24149A.

Aiuppa A. et al. (2010) Patterns in the recent 2007-2008 activity of Mount Etna volcano investigated by integrated geophysical and geochemical observations. Geochem. Geophys. Geosyst., 11, Q09008, doi:10.1029/2010GC003168.

Aloisi, M., Bonaccorso A., Cannavò F., Gambino S., Mattia M., Puglisi G. and Boschi E. (2009) A new dyke intrusion style for the Mount Etna May 2008 eruption modelled through continuous tilt and GPS data. Terra Nova, 21, 316-321, doi:10.1111/j.1365-3121.2009.00889.x.

Aubaud C., Pineau F., Jambon A., Javoy M. (2004) Kinetic disequilibrium of C, He, Ar and carbon isotopes during degassing of mid-ocean ridge basalts, Earth Planet. Sci. Lett. 222, 391-406.

Berlo K., Blundy J., Turner S., Cashman K., Hawkesworth C. and Black S. (2004) Geochemical precursors to volcanic activity at Mount St. Helens, USA. Science, 306, 1167-1169.

Bonaccorso A. and Davis P. M. (2004) Modeling of ground deformation associated with recent lateral eruptions: Mechanics of magma ascent and intermediate storage at Mount Etna In: (Calvari et al. Eds.) Mount Etna: Volcano Laboratory, Geophys. Monogr. Ser., AGU, Washington D.C, 143, pp. 293- 306,.

Budetta G., Carbone D., Greco F. and Rymer H. (2004) Microgravity studies at Mount Etna (Italy) In: (Calvari et al. Eds.) Mount Etna: Volcano Laboratory, Geophys. Monogr. Ser., AGU, Washington D.C, 143, pp. 221- 240.

Burnard P., Graham D. and Turner G. (1997) Vesicle-specific noble gas analyses of popping rock: implications for primordial noble gases in the Earth. Science, 276, 568-571.

Caracausi, A., Favara R., Giammanco S., Nuccio P.M., Paonita A., Pecoraino G. and Rizzo A.. (2003a) Mount Etna: Geochemical signals of magma ascent and unusually extensive plumbing system. Geophys. Res. Lett.,, 30, 1057-1060.

Caracausi, A., Italiano F., Nuccio P.M., Paonita A. and Rizzo A. (2003b) Evidence of deep magma degassing and ascent by geochemistry of peripheral gas emissions at Mt. Etna (Italy): assessment of the magmatic reservoir pressure. J. Geophys. Res, 108, 2463-2484.

Cartigny P., Harris J.W. and Javoy M. (2001) Diamond genesis, mantle fractionations and mantle nitrogen content: a study of $\delta^{13} \mathrm{C}-\mathrm{N}$ concentrations in diamonds. Earth Planet. Sci. Lett. 185, 85-98.

Cartwright J. and Hansen D. M. (2006) Magma transport through the crust via interconnected sill complexes. Geology, 34, 929-932.

Chiarabba C., Amato A., Boschi E. and Barberi F. (2000) Recent seismicity and tomographic modeling of the Mount Etna plumbing system. J. Geophys. Res., 105, 10923-10938.

Chiodini G., D’Alessandro W. and Parello F. (1996) Geochemistry of gases and water discharged by the mud volcanoes at Paternò, Mt. Etna (Italy). Bull. Volcanol., 58, 51- 58.

Chiodini G., Caliro S., Aiuppa A., Avino R., Granieri G., Moretti R., Parello F. (2010) First ${ }^{13} \mathrm{C} /{ }^{12} \mathrm{C}$ isotopic characterisation of volcanic plume $\mathrm{CO}_{2}$. Bull. Volcanol., online, doi:10.1007/s00445010-0423-2.

Clocchiatti R., Weisz J., Mosbah M. and Tanguy J. C. (1992) Coexistence de"verres" alcalins et thoeliitiques satures en $\mathrm{CO}_{2}$ dans les olivines des hyaloclastites d'Aci Castello (Etna, Sicilie, Italie): Arguments en faveur d'un manteau anormal et d'un reservoir profond, Acta Vulcanol., 2, 161-173.

Clocchiatti R., Condomines M., Guénot N. and Tanguy J.C. (2004) Magma changes at Mount Etna: the 2001 and 2002-2003 eruptions. Earth Planet. Sci. Lett., 226, 397-414.

Collins S. J., Pyle D. M. and Maclennan J. (2009) Melt inclusions track pre-eruption storage and dehydration of magmas at Etna. Geology, 37, 571-574, doi:10.1130/G30040A.1.

Corsaro, R. A. and Pompilio M. (2004) Buoyancy-controlled eruption of magmas at Mt Etna. Terra Nova, 16(1), 16 -22, doi:10.1046/j.1365-3121.2003.00520.x. 
Corsaro, R.A., Miraglia L. and Pompilio, M. (2007) Petrologic evidence of a complex plumbing system feeding the July-August 2001 eruption of Mt. Etna, Sicily, Italy. Bull. Volcanol. 69, 401-421.

Corsaro R. and Miraglia L. (2009) Dynamics of magma in the plumbing system of Mt. Etna volcano, Sicily, Italy: A contribution from petrologic data of volcanics erupted from 2007 to 2009. Eos Trans. AGU, 90(52), Fall Meet. Suppl., Abstract V51C-1690.

D’Alessandro W., De Gregorio S., Dongarrà G., Gurrieri S., Parello F. and Parisi B. (1997) Chemical and isotopic characterization of the gases of Mount Etna (Italy). J. Volcanol. Geotherm. Res., 78, 65-76.

Dawson P., Whilldin D. and Chouet B. (2004) Application of near real-time radial semblance to locate the shallow magmatic conduit at Kilauea Volcano, Hawaii. Geophys. Res. Lett., 31, L21606. doi:10.1029/2004GL021163.

De Gori P., Chiarabba C. and Patanè D. (2005) Qp structure of Mount Etna: Constraints for the physics of the plumbing system. J. Geophys. Res., 110, B05303, doi:10.1029/2003JB002875.

Edmonds M., Aiuppa A., Humphreys M., Moretti R., Giudice G., Martin R. S., Herd R. A. and Christopher T. (2010) Excess volatiles supplied by mingling of mafic magma at an andesite arc volcano, Geochem. Geophys. Geosyst., 11, Q04005, doi:10.1029/2009GC002781.

Ferlito, C., Viccaro, M. and Cristofolini, R. (2007) Volatile-induced magma differentiation in the plumbing system of Mt. Etna volcano (Italy): evidence from glass in tephra of the 2001 eruption. Bull. Volcanol., 70(4), 455-473.

Ferlito C. and Lanzafame G. (2010) The role of supercritical fluids in the potassium enrichment of magmas at Mount Etna volcano (Italy), Lithos, 119(3-4), 642-650, doi:10.1016/j.lithos.2010.08.006.

Fischer T.P., Takahata N., Sano Y., Sumino H. and Hilton D.R. (2005) Nitrogen isotopes of the mantle: Insights from mineral separates. Geophys. Res. Lett. 32, L11305, doi:10.1029/2005GL022792.

Giammanco S., Inguaggiato S. and Valenza M. (1998) Soil and fumarole gases of Mount Etna: Geochemistry and relations with volcanic activity. J. Volcanol. Geotherm. Res., 81, 297-310.

Graham D.W. (2002) Noble Gas Isotope Geochemistry of Mid-Ocean Ridge and Ocean Island Basalts: Characterization of Mantle Source Reservoirs. In: Porcelli, D., Ballantine, C.J., Wieler, R. (Eds.), Noble gases in Cosmochemistry and Geochemistry, Reviews in Mineralogy and Geochemistry, Mineralogical Society of America, Washington, 47, pp. 247-317.

Hilton D.R., Fisher T.P. and Marty B. (2002) Noble gases and volatile recycling at subduction zones. In: Porcelli, D., Ballantine, C.J., Wieler, R. (Eds.), Noble gases in Cosmochemistry and Geochemistry, Reviews in Mineralogy and Geochemistry, Mineralogical Society of America, Washington, 47, pp. 319-370.

Hirn A., Nicolich R., Gallart J., Laigle M., Cernobori L. and ETNASEIS Scientific Group (1997) Roots of Etna volcano in faults of great earthquakes, Earth Planet. Sci. Lett., 148, 171- 191.

Iacono-Marziano G, Gaillard F, Scaillet B, Pichavant M and Chiodini G. (2009) Role of non-mantle $\mathrm{CO}_{2}$ in the dynamics of volcano degassing: The Mount Vesuvius example. Geology, 37, 319-322.

Iacono Marziano G., Paonita A., Rizzo A., Gaillard F. and Scaillet B. (2010) Noble gas solubilities in silicate melts: new experimental results and a comprehensive model of the effects of liquid composition, temperature and pressure. Chem. Geol., 279, 145-157.

Javoy M., Pineau F. and Iiyama I. (1978) Experimental determination of the isotopic fractionation between gaseous $\mathrm{CO}_{2}$ and carbon dissolved in tholeiitic magma: a preliminary study, Contrib. Mineral. Petrol. 67, 35-39.

Johnson J.W., Oelkers E.H. and Helgeson H.C. (1992) SUPCRT92: A software package for calculating the standard molal thermodynamic properties of minerals, gases, aqueous species, and reactions from 1 to 5000 bars and $0^{\circ} \mathrm{C}$ to $1000^{\circ} \mathrm{C}$. Comput. Geosci., 18, 899-947, 1992.

Kamenetsky V. and Clocchiatti R. (1996) Primitive magmatism of Mt. Etna: Insights from mineralogy and melt inclusions, Earth Planet. Sci. Lett., 142, 553-572. 
Laigle M., Hirn H., Sapin M. and Lepine J.C. (2000), Mount Etna dense array local earthquake P and $\mathrm{S}$ tomography and implications for volcanic plumbing. J. Geophys. Res., 105, $21633-$ 21646.

La Spina A., Burton M. and Salerno G.F. (2010) Unravelling the processes controlling gas emissions from the central and northeast craters of Mt. Etna. J. Volcanol. Geotherm. Res., 198(3-4), 368-376, doi:10.1016/j.jvolgeores.2010.09.018.

Liotta M., Paonita A., Caracausi A., Martelli M., Rizzo A. and Favara R. (2010) Hydrothermal processes governing the geochemistry of the crater fumaroles at Mount Etna volcano (Italy). Chem. Geol., 278(1-2), 92-104.

Marsh B. (2004) A magmatic mush column Rosetta Stone: the McMurdo dry valleys of Antarctica. EOS Transactions, 85, 497-508.

Martelli M., Caracausi A., Paonita A. and Rizzo A. (2008) Geochemical variations of air-free crater fumaroles at Mt Etna: New inferences for forecasting shallow volcanic activity. Geophys. Res. Lett. 35, L21302, doi:10.1029/2008GL035118.

Mattey D.P (1991) Carbon dioxide solubility and carbon isotope fractionation in basaltic melt, Geochim. Cosmochim. Acta 55, 3467-3473.

Mattia M., Patanè D., Aloisi M. and Amore M. (2007) Faulting on the western flank of Mt Etna and magma intrusions in the shallow crust. Terra Nova, 19, 89-94, doi:10.1111/j.13653121.2006.00724.x.

Menand T. and Phillips J. (2007) Gas segregation in dykes and sills. J. Volcanol. Geotherm. Res., 159, 393-408.

Metrich N., Clocchiatti R., Mosbah M. and Chaussidon M. (1993) The 1989-90 activity of Etna: Magma mingling and ascent of $\mathrm{H}_{2} \mathrm{O}-\mathrm{Cl}-\mathrm{S}$-rich basaltic magma: Evidence from melt inclusions. J. Volcanol. Geotherm. Res., 59, 131-144.

Métrich N., Allard P., Spilliaert N., Andronico D. and Burton M. (2004) 2001 flank eruption of the alkali- and volatile-rich primitive basalt responsible for Mount Etna's evolution in the last three decades. Earth Planet. Sci. Lett., 228, 1-17.

Nuccio P.M. and Paonita A., (2000): Investigation of the He solubility in $\mathrm{H}_{2} \mathrm{O}-\mathrm{CO}_{2}$ bearing silicate liquids at moderate pressure II: the Extended Ionic Porosity (EIP) model, Earth Planet. Sci. Lett., 183, 499-512.

Nuccio P. M. and Paonita A. (2001) Magmatic degassing of multicomponent vapors and assessment of magma depth: application to Vulcano Island (Italy), Earth Planet. Sci. Lett., 193 (3-4), 467481.

Nuccio, M., A. Paonita, A. Rizzo and A. Rosciglione (2008) Elemental and isotope covariation of noble gases in mineral phases from Etnean volcanics erupted during 2001- 2005, and genetic relation with peripheral gas discharges, Earth Planet. Sci. Lett., 272, 683- 690.

Ohmoto, H. and Rye, R.O., (1979) Isotopes of sulfur and carbon. In: Barnes, H.L. (Ed.), Geochemistry of Hydrothermal Ore Deposits. John Wiley \& Sons Inc., New York, pp. 509567.

Paonita A., Gigli G., Gozzi D., Nuccio P.M. and Trigila R., (2000) Investigation of the He solubility in $\mathrm{H}_{2} \mathrm{O}-\mathrm{CO}_{2}$ bearing silicate liquids at moderate pressure: a new experimental method, Earth Planet. Sci. Lett., 181, 595-604.

Paonita, A. and Martelli, M. (2007) A new view of the $\mathrm{He}-\mathrm{Ar}-\mathrm{CO}_{2}$ degassing at mid-ocean ridges: Homogeneous composition of magmas from the upper mantle. Geochim. Cosmochim. Acta, 71(7), 1747-1763.

Paonita A. (2010) Long-range correlation and nonlinearity in geochemical time series of gas discharges from Mt. Etna, and changes with 2001 and 2002-03 eruptions. Nonlin. Processes Geophys., 17, 733-751.

Papale P., Moretti R. and D. Barbato (2006) The compositional dependence of the saturation surface of $\mathrm{H}_{2} \mathrm{O}+\mathrm{CO}_{2}$ fluids in silicate melts. Chem. Geol., 229,78-95. 
Paulatto M., Minshull T.A. and Henstock T.J. (2010) Constraints on an intrusive system beneath the Soufriére Hills Volcano, Montserrat, from finite difference modelling of a controlled source seismic experiment. Geophys. Res. Lett., 37, L00E01, doi:10.1029/2009GL041805.

Preston R.J. (2001) Composite minor intrusions as windows into subvolcanic magma reservoir processes: mineralogical and geochemical evidence for complex magmatic plumbing systems in the British Tertiary Igneous Province. J Geol. Soc., 158, 47-58.

Rizzo A., Caracausi A., Favara R., Martelli M., Paonita A., Paternoster M., Nuccio P.M. and Rosciglione A. (2006) New Insights into magma dynamics during last two eruptions of Mount Etna as inferred by geochemical monitoring from 2002 to 2005. Geochem., Geophys. Geosyst., 7, doi:10.1029/2005GC001175.

Sano Y., Gamo T. and Williams S. N. (1997) Secular variations of helium and carbon isotopes at Galeras volcano, Colombia. J. Volcanol. Geotherm. Res., 77, 255-265.

Schiano P, Clocchiatti R, Ottolini L and Busa`T. (2001) Transition of Mount Etna lavas from a mantle-plume to an island-arc magmatic source. Nature, 412, 900-904.

Shinohara H., Aiuppa A., Giudice G., Gurrieri S. and Liuzzo M. (2008) Variation of $\mathrm{H}_{2} \mathrm{O} / \mathrm{CO}_{2}$ and $\mathrm{CO}_{2} / \mathrm{SO}_{2}$ ratios of volcanic gases discharged by continuous degassing of Mount Etna volcano, Italy. J. Geophys. Res., 113, B09203, doi:10.1029/2007JB005185.

Sparks, R. S. J. (2003) Forecasting volcanic eruptions. Earth Planet. Sci. Lett., 210, 1-15.

Spilliaert N., Allard P., Mètrich N. and Sobolev A.V. (2006) Melt inclusion record of the conditions of ascent, degassing, and extrusion of volatile-rich alkali basalt during the powerful 2002 flank eruption of Mount Etna (Italy). J. Geophys. Res., 111, B04203. doi:10.1029/2005JB003934.

Thomson K. (2004) Sill complex geometry and internal architecture: a 3D seismic perspective. In: Petford N, Breitkreuz C (eds) Physical geology of high-level magmatic systems. Geol. Soc Lond. Spec. Pub., 234, 229-232.

Tonarini S, Armienti P, D’Orazio M and Innocenti F (2001) Subduction-like fluids in the genesis of Mt. Etna magmas: evidence from boron isotopes and fluid mobile elements. Earth Planet Sci Lett., 192, 471-483.

Trull T., Pineau F., Bottinga Y. and Javoy M. (1992) $\mathrm{CO}_{2}$ bubble growth and ${ }^{13} \mathrm{C} /{ }^{12} \mathrm{C}$ isotopic fractionation in basaltic melt, Eos 73, 348.

Viccaro, M. and Cristofolini, R. (2008) Nature of mantle heterogeneity and its role in the short-term evolution of Mt. Etna (Italy). Lithos, 105, 272-288.

Viccaro M., Nicotra E., Millar I.L. and Cristofolini, R. (2011) The magma source at Mount Etna volcano: perspectives from the $\mathrm{Hf}$ isotope composition of historic and recent lavas. Chem. Geol., 281, 343-351.

Zellmer G. F. and Annen C. (2008) An introduction to magma dynamics. Geological Society, London, Special Publications, 304, 1-13, doi:10.1144/SP304.1. 
Figure 1. Map of sampled vents. The photo shows a detail of the investigated field of fumaroles at the Voragine crater.

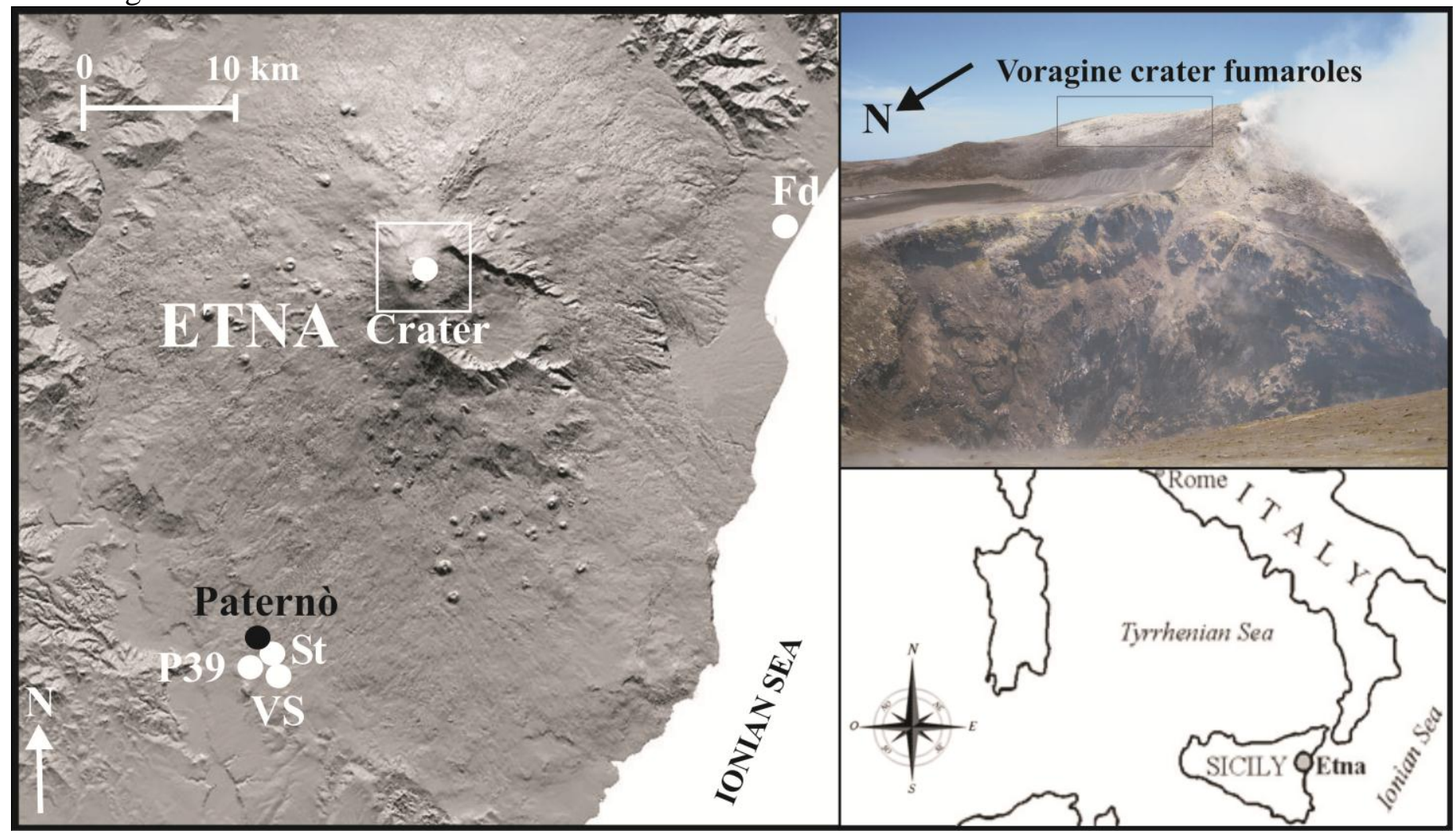

Figure 2. Ar isotopic composition of peripheral sites and crater fumaroles. The arrows show the mixing of air $\left[{ }^{36} \mathrm{Ar} /{ }^{40} \mathrm{Ar}=3.38 \times 10^{-3} ; \mathrm{Ar}=9300 \mathrm{ppm}\right]$ with three possible endmembers having low Ar contents and ${ }^{36} \mathrm{Ar} /{ }^{40} \mathrm{Ar}=3.33 \times 10^{-5}$ (i.e. ${ }^{40} \mathrm{Ar} /{ }^{36} \mathrm{Ar}$ ratio of $3 \times 10^{4}$ ).

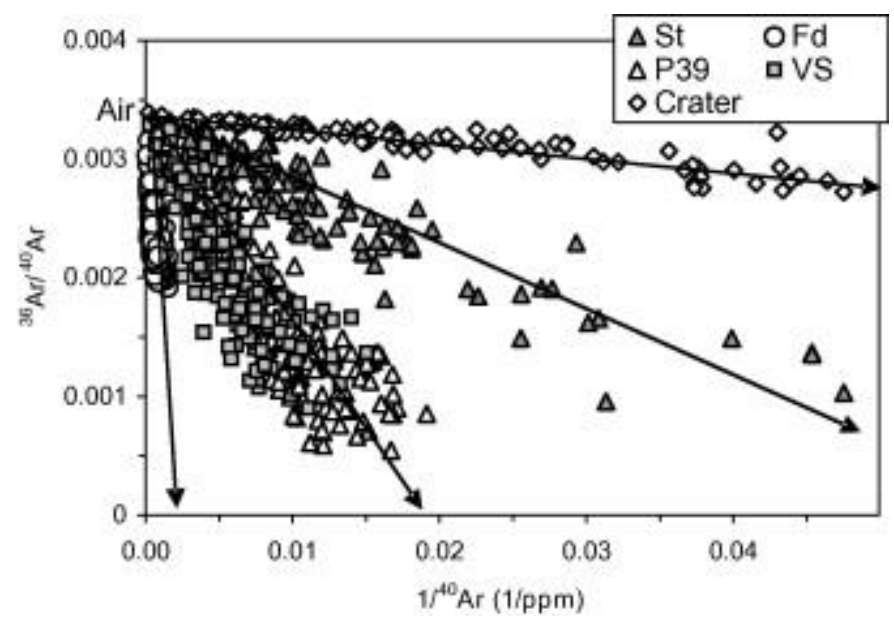


Figure 3. Ratios $\mathrm{Ar} * / \mathrm{CO}_{2}$ (a) and $\mathrm{He} / \mathrm{CO}_{2}$ (b) versus $\mathrm{CO}_{2}$ concentrations. The thick arrows display the paths of gas fractionation due to selective dissolution in a hot $\left(130^{\circ} \mathrm{C}\right)$ aquifer, computed by using the model of Caracausi et al. (2003b) after its upgrade to include Ar. The fractionation is able to explain the composition of all sites, over four orders of magnitude, starting from a single initial gas. The Eq.A7 in Caracausi et al. (2003b) was applied to include Ar in the dissolution model. The required solubility ratio between $\mathrm{Ar}$ and $\mathrm{CO}_{2}$ was $\sim 9$, computed by the SUPCRT code (Johnson et al., 1992). Changes of this ratio due to reasonable uncertainties in the conditions of the hot aquifer $(\mathrm{T}, \mathrm{P}, \mathrm{pH}$ ) do not practically affect the depicted path (see Caracausi et al. 2003b for a quantitative discussion).
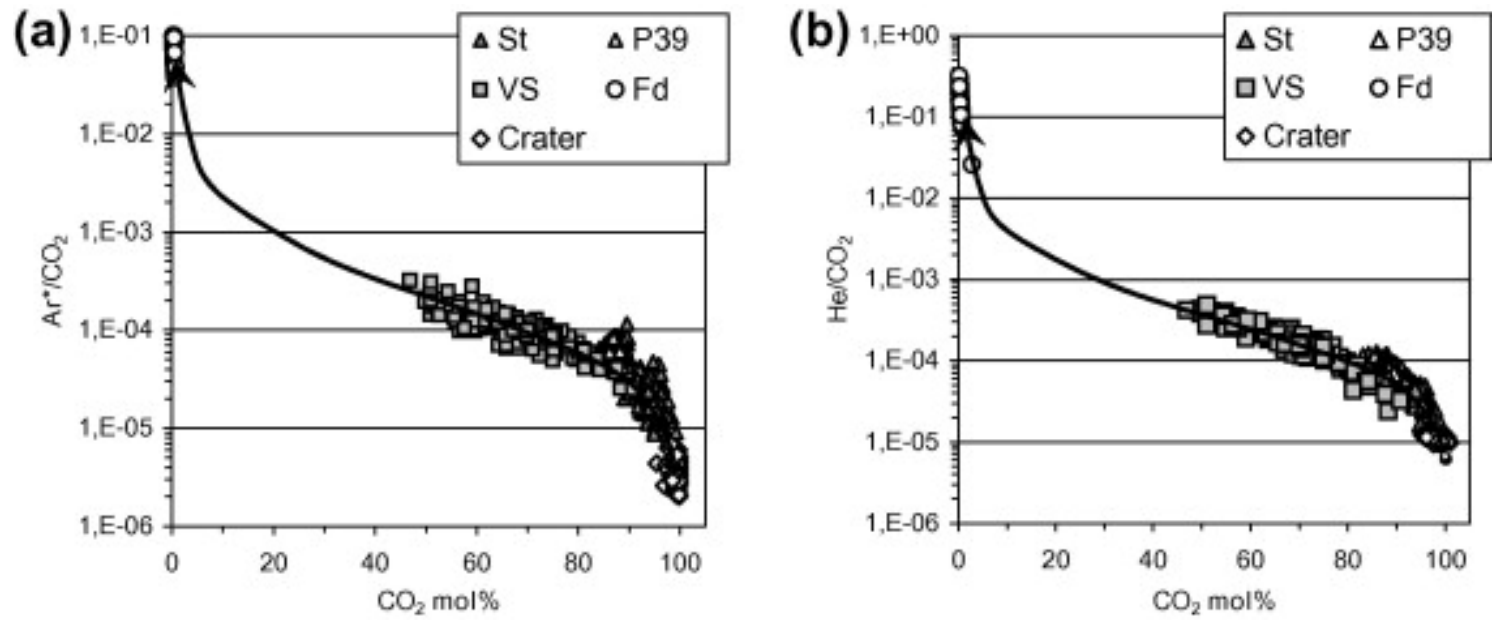

Figure 4. Variations of $\mathrm{He} / \mathrm{Ne}$ ratio at $\mathrm{Fd}$ site since 2001. The thick line is a moving average over two months. During 2001-2003, the He/Ne ratio was plainly higher than subsequent to 2004, suggesting small air contribution.

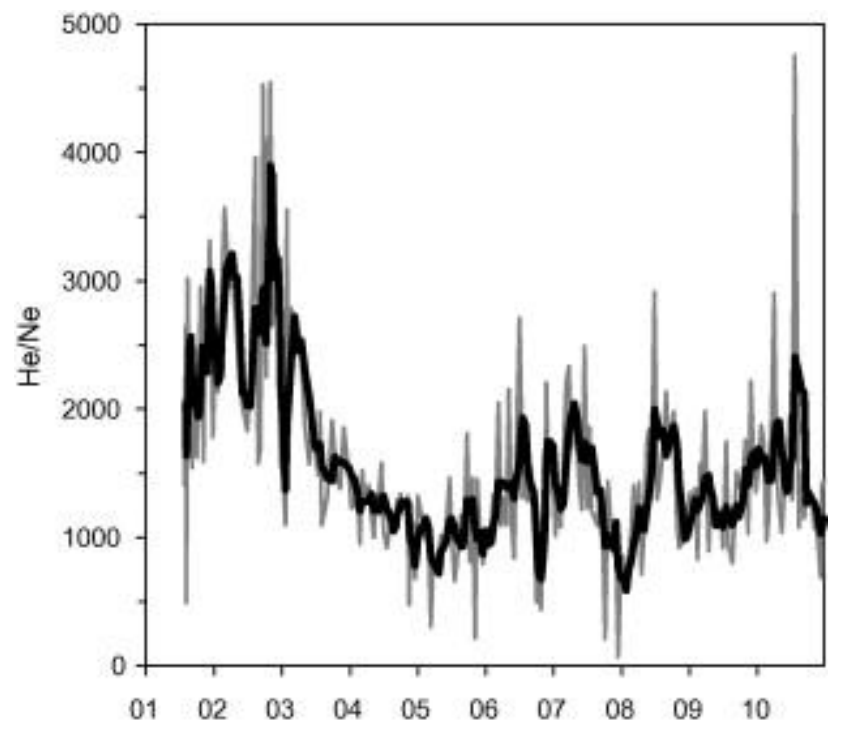


Figure 5. Changes of $\mathrm{He} / \mathrm{CO}_{2}$ and $\delta^{13} \mathrm{C}_{\mathrm{CO} 2}$ in a residual vapour phase after fractional dissolution in boiling aquifer at 100 bar and $320^{\circ} \mathrm{C}$, computed by the model of Liotta et al. (2010). According to the model, the gas mixture interacts with a infinitesimal parcel of liquid water that is subsequently separated from the residual gas, the process being repeated incrementally by interaction with further parcels of water. All the dissolution paths calculated at boiling conditions above 50 bar and $260{ }^{\circ} \mathrm{C}$ are very similar. The dotted area displays the range of $\mathrm{CO}_{2}$ residual fraction for crater fumaroles (details in Liotta et al., 2010).

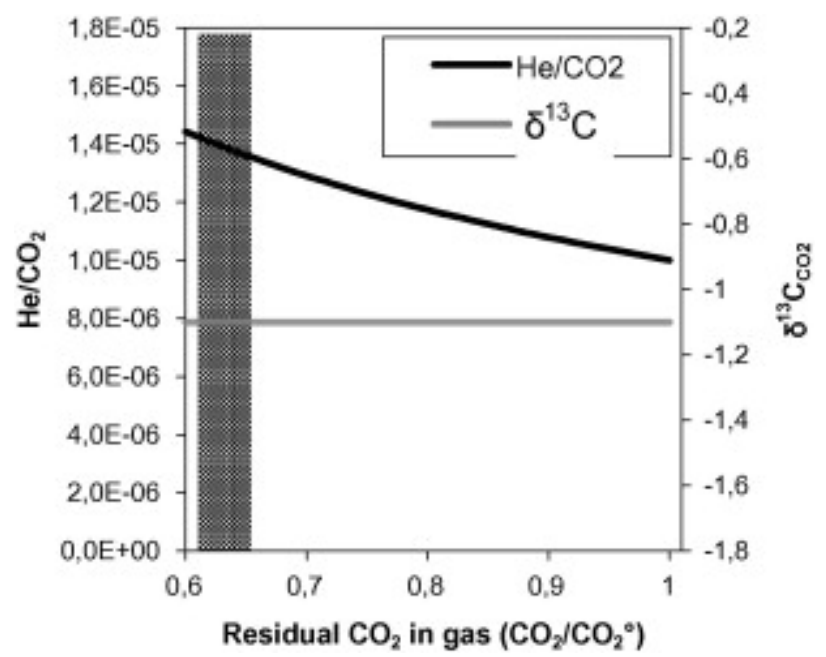


Figure 6. He-Ar- $\mathrm{CO}_{2}$ systematics of peripheral vents and crater fumaroles (the inset shows a larger compositional range). All data of peripheral vents have been corrected for selective dissolution in aquifers (see text). In the case of the fumaroles, each magmatic He and Ar* value was calculated by considering that the samples from different fumaroles at the same date represent a mixing of air and a magmatic endmember, and by extrapolating the magmatic value that best fits the data (see text). The related uncertainties are showed by an average error bar. The inset includes all the investigated vents, whereas the main graph only displays crater fumaroles and P39 vent, which are averagely the shallowest and deepest sampling of the magmatic system, respectively (see text). Crater data of 08/07/09 and 22/09/10 are also highlighted. Curves named as " $\mathrm{P}^{\circ}=450$, open" and " $\mathrm{P}$ " $=450$, closed" refer to open and closed system degassing at the boundary and initial conditions selected in the text (labelled numbers are pressures, initial degassing pressure is $450 \mathrm{MPa}$ ); curve " $\mathrm{P}^{\circ}=350$, open" is open system degassing with the same conditions but an initial pressure of $350 \mathrm{MPa}$. Curve named "mixing 400 to 130 " refers to binary mixing between an exsolved vapour at $400 \mathrm{MPa}$ and one exsolved at $130 \mathrm{MPa}$ (labelled numbers are percentages of high-pressure endmember), whereas in curve "mixing 400 to 100 " the shallow endmember is exsolved at $100 \mathrm{MPa}$.

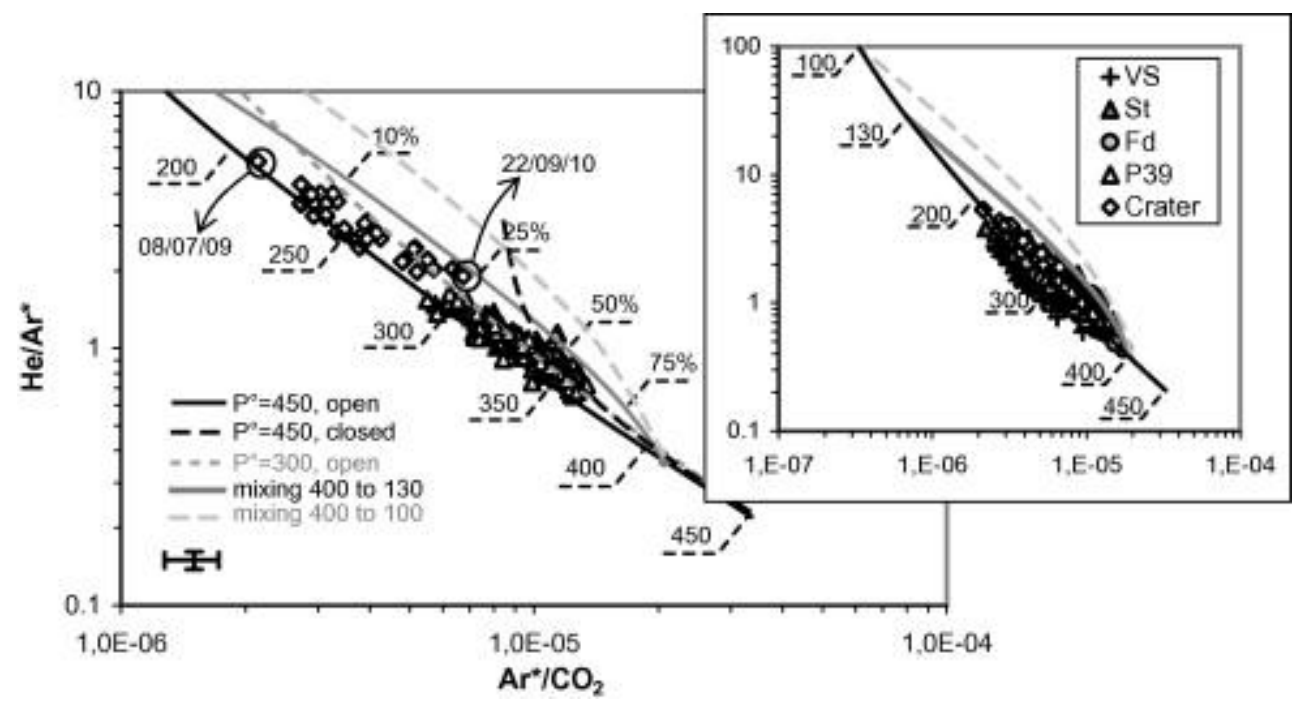

Figure 7. Relationship between $\delta^{13} \mathrm{C}_{\mathrm{CO} 2}$ and $\mathrm{He} / \mathrm{Ar}^{*}$ of crater fumaroles (the inset shows a larger compositional range). Main plot: the highlighted periods are pre-eruptive (17/07/07 to 22/05/08), sin-eruptive (18/08/08 to 29/06/09), after the end of eruption (08/07/09); open system degassing from $450 \mathrm{MPa}$ is showed as a black line; gray curves are binary mixing of the $130 \mathrm{MPa}$ shallow endmember with four deep endmembers exsolved at different pressures (labelled in figure); EML refers to the extreme mixing line (i.e., mixing between vapors exsolved at 400 and $130 \mathrm{MPa}$, see text); the average uncertainty is also showed. Inset: black line and thick gray line are as in the main plot; labels on the black line are degassing pressures, marks on the thick gray curve are mixing percentages $(25 \%, 50 \%$ and $75 \%$ of deep endmember); thin gray curve shows binary mixing between an exsolved vapour at $400 \mathrm{MPa}$ and one exsolved at $100 \mathrm{MPa}$ (i.e., EML). For all the degassing paths, $\delta^{13} \mathrm{C}_{\mathrm{CO} 2}$ for the whole system is $-1.1 \%$ (namely, the initial $\delta^{13} \mathrm{C}_{\mathrm{CO} 2}$ value of magmatic gas is $+1.9 \%$, with $\varepsilon_{\text {vap-melt }}=+3 \%$ ), which allows all our data to be enclosed between degassing and extreme mixing line. Changes of $\varepsilon_{\mathrm{vap} \text {-melt }}$ within the $\pm 1 \%$ o uncertainty require variations of the whole-system $\delta^{13} \mathrm{C}_{\mathrm{CO} 2}$ value by $\pm 0.5 \%$. 


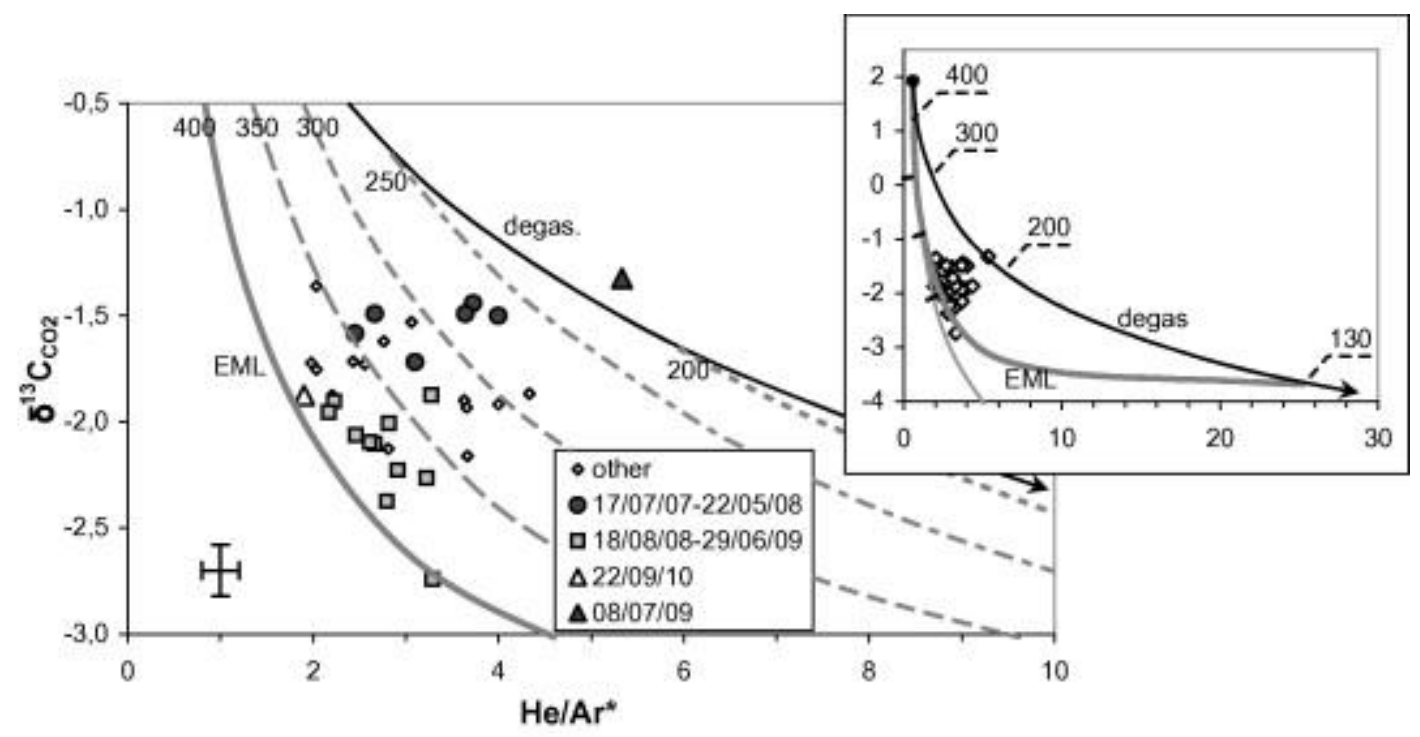

Figure 8. a) $\mathrm{He} / \mathrm{Ar}$, b) $\mathrm{Ar} / \mathrm{CO}_{2}$ and $\delta^{13} \mathrm{C}_{\mathrm{CO} 2}$ as a function of degassing pressure, computed by our isothermal $\left(1150^{\circ} \mathrm{C}\right)$ degassing model starting from $450 \mathrm{MPa}$ and $75 \mathrm{~mol} \% \mathrm{CO}_{2}$ in the initial vapour. Open (continuous lines) and closed (dashed lines) system conditions are shown. In a) we also show the ranges of measured $\mathrm{He} / \mathrm{Ar}^{*}$ values for both peripheral vents and crater fumaroles (double arrows). Their projection to the open system path constraints the pressure interval at which the sampled gases exsolve.

(a)

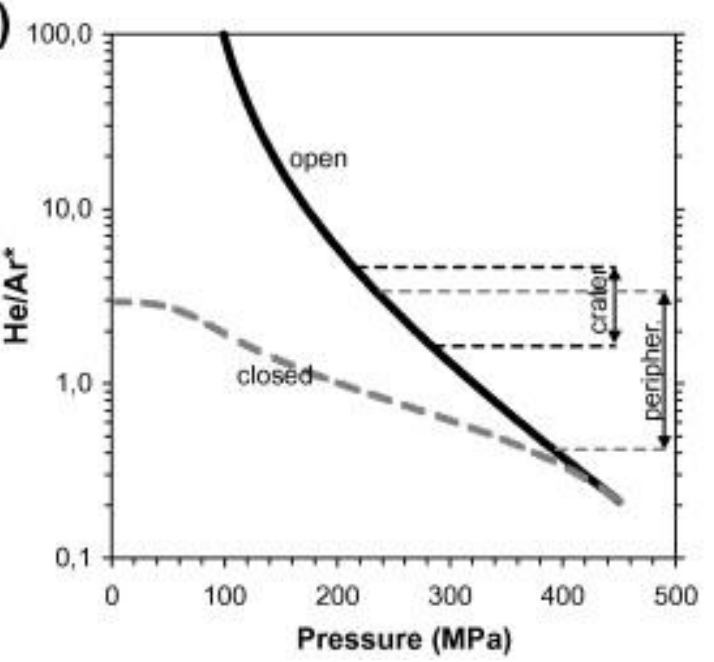

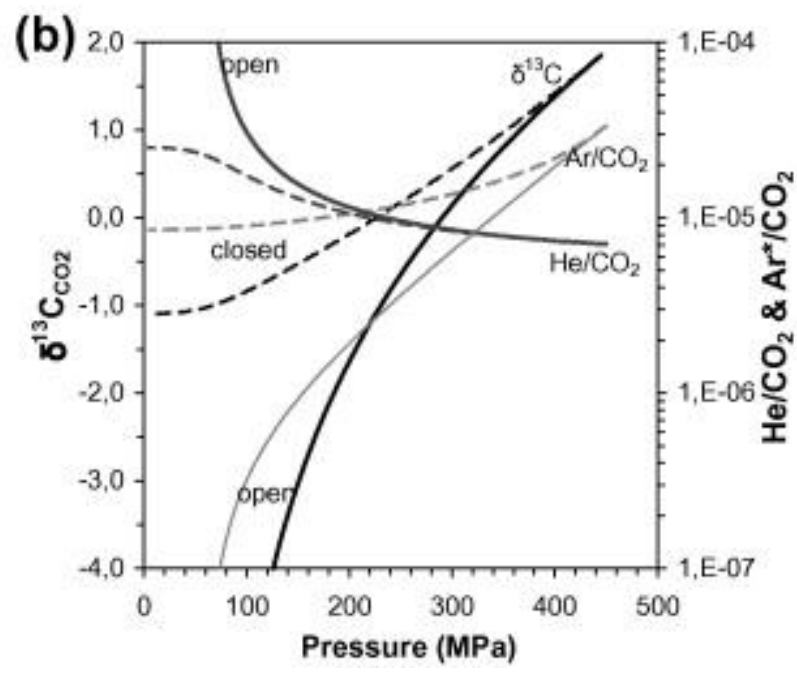


Figure 9. Time variations of $\mathrm{R} / \mathrm{Ra}$ and $\delta^{13} \mathrm{C}_{\mathrm{CO} 2}$ at fumaroles of Voragine crater (values and error bars for each date come from best fit of fumaroles sampled at that date, see text). The two marked periods (double arrows) are from 17/07/07 to 22/05/08 and from 18/08/08 to 29/06/09 (see text). On the top we show main periods of effusive volcanic activity (thick lines): explosive and effusive episodes at South-East crater during 2007, fire fountaining on 10 May 2008 at SEC, and the eruption started on 13 May 2008 and lasted until 6 July 2009 (Aloisi et al., 2009).

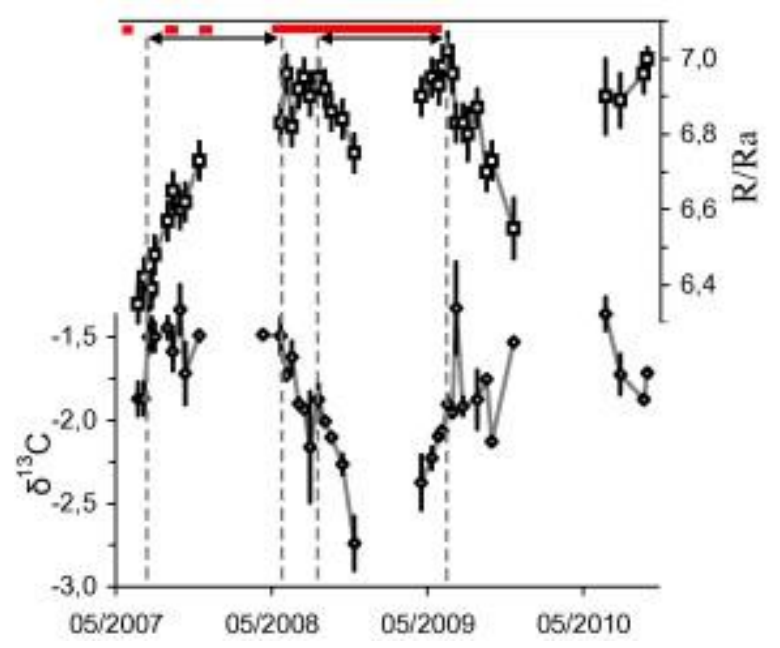

